\title{
Hypothermic Blood Substitution: Special Considerations for Protection of Cells during ex vivo and in vivo Preservation
}

\author{
Michael J. Taylor \\ Cell and Tissues Systems, N. Charleston, SC, USA
}

\section{Key Words}

Hypothermia - Preservation - Ischemia - Blood substitution Hemorrhagic shock

\section{Summary}

Clinical applications of hypothermia range from ex vivo storage of cells, tissues and organs for transplantation or cell-based therapies to in vivo protection of a patient during complex surgeries that might entail circulatory and/or cardiac arrest. The intent of this brief review is to outline the essential principles of hypothermia applied in the preservation of cells for a multitude of clinical purposes. The focus will be confined to our ability as interventionalists to control the environment of cells to optimize hypothermic preservation. More specifically, this review will summarize the design principles of hypothermic blood substitutes (HBS) defined as preservation solutions for protection of cells, tissues and organs during a hypothermic preservation interval. In contrast to the types of solutions that have been used historically as hemodiluents for clinical hypothermia, i.e. normal physiologically balanced salt solutions, our approach has been to design aqueous blood substitutes that embody many of the principles now identified as contributory and important for optimal ex vivo organ preservation. The working hypothesis that we have addressed using a variety of pre-clinical large animal models is that acellular solutions can be designed to act as universal tissue preservation solutions during several hours of hypothermic whole-body washout involving cardiac arrest, with or without circulatory arrest. On this basis, two new types of solutions, designated 'Purge' and 'Maintenance' HBS, have been formulated and evaluated to fulfill separate requirements during the asanguineous procedure. The evidence supporting this concept is reviewed in the context of imminent clinical trials to apply this novel technique for the preservation and resuscitation of trauma victims suffering hemorrhagic shock.

\author{
Schlüsselwörter \\ Hypothermie · Konservierung · Ischämie · Blutersatz · \\ Hämorrhagischer Schock
}

\section{Zusammenfassung}

Klinische Anwendungen der Hypothermie erstrecken sich von der Ex-vivo-Lagerung von Zellen, Geweben und Organen zur Transplantation über zellbasierte Therapieformen bis zum Invivo-Schutz des Patienten während komplexer chirurgischer Eingriffe, die einen zirkulatorischen oder kardialen Stillstand beinhalten können. Diese kurze Übersichtsarbeit versucht, die essentiellen Prinzipien der Hypothermie darzustellen, wie sie zur Konservierung von Zellen für eine Vielzahl von klinischen Zwecken eingesetzt werden. Der Fokus liegt dabei auf unserer Fähigkeit als "Interventionalisten", die Umgebung der Zellen für die hypotherme Konservierung zu optimieren. Insbesondere fasst diese Übersichtsarbeit die Prinzipien des "Designs" von hypothermen Blutersatzstoffen (HBS) zusammen, die als Konservierungslösungen zum Schutz von Zellen, Geweben und Organen während der hypothermen Konservierungsphase gedacht sind. Im Gegensatz zu solchen Lösungen, die historisch zur Hämodilution bei der klinischen Hypothermie eingesetzt wurden, d.h. normale ausbalancierte physiologische Salzlösungen, ist es unser Ansatz, solche Blutersatzlösungen zu entwerfen, die viele der Prinzipien berücksichtigen, die heute für unterstützend und bedeutsam für die Ex-vivo-Organkonservierung gehalten werden. Die Arbeitshypothese, derer wir uns bei einer Vielzahl von präklinischen Modellen mit Großtieren bedient haben, war, zellfreie Lösungen zu entwerfen, die als universelle Konservierungslösungen während der einige Stunden dauernden Ganzkörper-«wash out»-Phase bei Herzstillstand, mit oder ohne zirkulatorischen Stillstand, dienen können. Auf dieser Basis haben wir zwei neue Arten von HBS-Lösungen für "Purge" (Auswaschen) und "Maintenance" (Aufrechterhaltung) geschaffen und untersucht, die den unterschiedlichen Anforderungen während der blutlosen Phase gerecht werden. Das, was dieses Konzept unterstützt, wird im Zusammenhang mit bevorstehenden klinischen Studien erörtert, bei denen diese neue Technik zur Konservierung und Flüssigkeitsversorgung von Traumapatienten mit hämorrhagischem Schock angewendet werden soll.

\begin{tabular}{ll}
\hline KARGER & @ 2007 S. Karger GmbH, Freiburg \\
Fax +49 76145207 14 & Accessible online at: \\
$\begin{array}{l}\text { E-mail Information@Karger.de } \\
\text { www.karger.com }\end{array}$ & www.karger.com/tmh
\end{tabular}




\section{Introduction}

The fundamental principle of cellular preservation for clinical application is to minimize the deleterious effects of ischemia and anoxia during the preservation interval. This can either be achieved pharmacologically by using a wide variety of cytoprotective drugs and/or by reducing temperature. Interestingly, conventional wisdom teaches us that there is no single drug, or cocktail of drugs, that can so safely and effectively suppress metabolism and provide ischemic protection for multiple tissues and organs as the application of hypothermia can. Hence, the intent of this brief review is to outline the essential principles of hypothermia applied in the preservation of cells for a multitude of clinical purposes. This is a comprehensive topic that cannot be covered adequately in a brief article, and the reader will be referred to supplementary recent reviews for more detail. Here the focus will be confined to our ability as interventionalists to control the environment of cells to optimize hypothermic preservation. More specifically, this review will summarize the design principles of hypothermic blood substitutes defined as preservation solutions for protection of cells, tissues and organs.

Clinical applications of hypothermia range from ex vivo storage of cells, tissues and organs for transplantation or cell-based therapies to in vivo protection of a patient during complex surgeries that might entail circulatory and/or cardiac arrest $[1$, 2]. The latter is a very specialized area of current research that is regarded as the only feasible approach to safely extend the window of opportunity available to surgeons who need more time to perform complex, corrective and life-saving operations; notably on the heart and brain. Many of these complicated time consuming procedures have the inherent need for temporary cessation of blood flow and have demanded protection of the different organs of the body, especially the brain, against the deleterious effects of ischemia and anoxia.

With this background in mind, the objective here is to review for an audience interested in transfusion medicine the current principles of hypothermic blood substitution as a basis for cellular protection in isolated organs as well as the whole body.

\section{The Clinical Perspective and Problem - Need for Bloodless Surgery}

Today, surgeons have developed skills that allow very complex, corrective and life-saving operations to be performed; notably on the heart and brain. Many of these complicated time consuming procedures have the inherent need for temporary cessation of blood flow and have demanded protection of the different organs of the body, especially the brain, against the deleterious effects of ischemia and anoxia. Common examples of such operations include open-heart surgery, especially in infants to repair congenital cardiac defects; neurosurgical problems in adults, such as giant cerebral aneurysms and other vascular lesions; resection of tumors associated with major blood vessels; and surgical repair of aneurysms of the aortic arch. Because of their high metabolic demand requiring large amounts of oxygen and glucose, the central nervous system and myocardium are especially vulnerable to the rapid onset of ischemic injury, and hypothermia is frequently used as an adjunctive technique for surgical procedures that require a period of circulatory and/or cardiac arrest.

It has been known for centuries that the application of cold can be protective [3], and potential clinical benefits of hypothermia in the 20th century were recognized as early as 1939 when it was demonstrated that surface cooling of an ischemic limb in rats improved overall survival [4]. However, it was not until the introduction of cardiopulmonary bypass (CPB) in the early 1950s that hypothermia became widely used clinically [5, 6]. Lowering the temperature of a euthermic subject to a temperature below that normally maintained by homeostasis reduces the metabolic rate and hence the demand for oxygen and substrates by the tissues. On this basis, many modern day surgical procedures, particularly in the areas of cardiovascular surgery, neurosurgery, and sometimes in trauma, rely on some degree of imposed or regulated hypothermia as a relatively safe modality for effecting biologic protection during circulatory and/or cardiac arrest [1]. Nevertheless, total body hypothermic protection, or 'clinical suspended animation', remains time limited by the tolerance of those tissues most sensitive to an ischemic insult, even at reduced temperatures. Currently, the accepted safe limits of cardiac arrest are less then $60 \mathrm{~min}$ at temperatures no lower than $16-18^{\circ} \mathrm{C}$. It is well established that exceeding these limits markedly increases the risks of clinical sequelae, especially neurological complications in patients [7-10]. This imposes severe time constraints for a variety of surgical procedures that are otherwise technically feasible, and it remains a major goal for surgeons to extend the safe limits of hypothermic arrest beyond the present $1 \mathrm{~h}$ limit. Our experimental approach which, in a significant departure from techniques that rely upon moderate to deep hypothermia and hemodilution, employs ultraprofound hypothermia and blood substitution (UHBS) is described below.

\section{Basics of Cellular Hypothermia}

At the cellular level, the fundamental basis of hypothermic protection is the effect of temperature on reaction rates which, according to Arrhenius' theory, are generally slowed by a reduction in temperature. Since the processes of deterioration associated with ischemia and anoxia are mediated by chemical reactions, it has proved well founded to attempt to prevent or attenuate these changes by applying hypothermia. Although our knowledge of the mechanisms of ischemic injury is far from complete, there is a considerable degree of understanding of the cascade of events that is initiated by oxygen depri- 
vation. These deleterious changes begin with early onset biochemical events arising from the immediate depletion of high energy reserves (adenosine triphosphate (ATP) and creatine phosphate $(\mathrm{CP})$ ) and membrane depolarization, and culminating in structural changes and eventually cell death. Whilst hypothermia is known to influence reaction rates, energy metabolism, active ion transport and ion homeostasis, membrane fluidity and function, and the secretion of hormones and neurotoxins, the effects are not exclusively beneficial, and harmful effects of hypothermia have to be 'weighed in the balance'. At the systemic level the theoretical basis for protecting the brain and vital organs during ischemia and hypoxia relies principally upon the effect of temperature reduction upon metabolism and oxygen demand.

\section{The Cell in Relation to Its Environment and the Essential Role of the Circulation}

Within the body, the extracellular fluid bathing cells is maintained within closely regulated limits by a variety of control mechanisms, and cells maintain a different, but even more constant intracellular milieu. Cells are able to maintain a stable internal environment very different from that which surrounds them by means of their membrane pumps, such that inhibition of these ionic pumps by substrate deprivation, cooling, or poisoning leads initially to reversible perturbations of cellular homeostasis such as ionic balances and hydration. Eventually, these processes become irreversible and permanent injury is sustained.

In considering the fundamental processes of normal cellular function and homeostasis as a prelude to discussing the nature of ischemic injury and its prevention, it is important to emphasize the essential role of the circulation. The well known basics of how a cell is sustained for normal function and the composition and regulation of the interstitial fluid are important functions of the circulation. Other essential functions include the provision of an internal heat transfer system that closely regulates the temperature of tissues and organs. The circulation transports metabolites of which the fuels for respiration (glucose, fatty acids, and ketone bodies) are most important in the short term. For most tissues, respiration is predominantly aerobic with high demands for oxygen (e.g. $300 \mathrm{ml}$ $\mathrm{O}_{2}$ per min/g dry weight of kidney renal cortex). The solubility of oxygen in tissue fluid is only about $24 \mathrm{ml} / \mathrm{kg}$ such that inhibition of aerobic energy production is very rapid following the onset of ischemia. Other necessary metabolites, besides those required for energy production, including amino acids, vitamins, glutathione, coenzymes and many other factors, are also supplied to cells via the circulation. The catabolic products of cellular metabolism are removed by the vascular system. In light of the crucial role of the circulation in sustaining the normal environment and metabolic needs of cells, it is possible to appreciate the devastating consequences of a disruption to the vascular supply of a tissue or organ. A brief consideration will now be given to the effects of ischemia as a preface to a discussion of the positive and negative aspects of hypothermia as a protective modality against ischemic injury.

\section{Hypothermia in Relation to Ischemic Events}

A great deal is known about the effects of cold on cells since cooling has proved to be the foundation of nearly all effective methods of protecting and preserving cells and tissues for applications such as transplantation. Transplantation science calls for effective methods of preservation since it is unavoidable that donor cells, tissues and organs are required to withstand a period of ischemia and hypoxia as part of any transplantation procedure when the blood supply is temporarily interrupted. The basis of this hypothermic protection is that cooling can help to combat the deleterious effects of ischemia, but the consequences of cooling are not exclusively beneficial such that hypothermic storage is a compromise between the benefits and detriments of cooling $[2,11,12]$. In this account a brief summary of the detrimental effects only of hypothermic stress on cells will be outlined. A more complete account of the biology of cell survival in the cold has recently been published elsewhere [2].

\section{General Suppression of Reaction Rates}

The fundamental basis of all biologic and chemical processes is molecular activity and mobility, which are governed by thermal energy, such that as temperature is lowered molecular motion is slowed. The removal of heat from a system slows down both physical and chemical processes in proportion to the loss of heat and therefore to the fall in temperature. Since the processes of deterioration associated with ischemia and anoxia are mediated by chemical reactions, it has proved well founded to attempt to prevent or attenuate these changes by cooling. Biochemical processes involve molecular interactions that are invariably catalyzed by enzymes in reactions that require energy input from cellular stores such as ATP or CP. Cooling can affect all components of these reactions, including the energy status of the substrate molecules, the stability of the enzyme protein, and the capacity of the cell to supply biological energy. The rate of biophysical processes such as diffusion of ions and osmosis declines linearly with temperature by approximately $3 \%$ per $10{ }^{\circ} \mathrm{C}$. It is apparent, therefore, that biophysical events are relatively little affected by the comparatively modest temperature changes imposed during hypothermic storage of tissues for transplantation. It is only at much lower temperatures that the rates of biophysical processes become significantly important, especially at sub zero temperatures when phase changes lead to both ice formation and solute concentration changes. 
By comparison, the rate of chemical reactions, including the biochemical processes that constitute metabolic activity, is slowed significantly more by a given degree of hypothermic exposure. It is well established that within the temperature range $0-42{ }^{\circ} \mathrm{C}$ oxygen consumption in tissues decreases by at least $50 \%$ for each $10{ }^{\circ} \mathrm{C}$ fall in temperature. The quantitative relationship between energy requirements for biochemical processes and temperature changes have been expressed mathematically in different ways:

i) The Arrhenius relationship: Biochemical processes, in common with all chemical reactions, occur only between activated molecules the proportion of which in a given system is given by the Boltzman expression exp $(-\mathrm{E} / \mathrm{RT})$ where $\mathrm{E}$ is the activation energy, $\mathrm{R}$ is the gas constant and $\mathrm{T}$ is the absolute temperature. According to the Arrhenius relationship, the logarithm of the reaction rate $(\mathrm{k})$, is inversely proportional to the reciprocal of the absolute temperature:

$-\log \mathrm{k}=\mathrm{A}(-\mathrm{E} / 2.3 \mathrm{RT})$

A graphical plot of $\log \mathrm{k}$ against $1 / \mathrm{T}$ will yield a straight line with a slope of $\mathrm{E} / 2.3 \mathrm{R}$ if the relationship represents a single rate-limiting step.

ii) Van't Hoff rule relates the logarithm of a chemical reaction rate directly to temperature and is commonly expressed in the form of the respiratory quotient or temperature coefficient, $\mathrm{Q}_{10}$, where $\mathrm{Q}_{10}$ is the ratio of reaction rates at two temperatures separated by $10{ }^{\circ} \mathrm{C}$ :

$\mathrm{Q}_{10}=\left(\mathrm{K}_{2} / \mathrm{K}_{1}\right) 10^{(\mathrm{T} 2-\mathrm{T} 1)}$

For most reactions of biological interest $\mathrm{Q}_{10}$ has a value between 2 and 3, but some complex, energy-dependent reactions have a $\mathrm{Q}_{10}$ between 4 and 6, and are more likely to stop completely at low temperatures. Both $\mathrm{Q}_{10}$ and Arrhenius plots have been used to quantitate changes in metabolic processes occurring in biologic systems, whether they are enzyme reactions in single cells or the oxygen consumption of the entire human body. The $\mathrm{Q}_{10}$ for wholebody oxygen consumption is approximately 2 indicating that, in general, metabolic rate is halved for each $10{ }^{\circ} \mathrm{C}$ drop in temperature.

\section{Metabolic Uncoupling}

While it is clear that cooling has a profound effect upon biochemical reaction rates and that this in turn can slow degradative processes and reduce the rate of substrate and energy depletion, it is important to realize that not all reaction rates are affected to the same degree, or even in the same manner, by cooling. One hypothesis of chilling injury states that at a certain critical temperature within the chilling injury range, the membrane lipids undergo a transition from a liquid-crystalline to a solid gel state. The two main consequences of the transition thought to eventually result in cell injury are an increase in membrane permeability and an increase in the activation energy of membrane bound enzymes such as those controlling respiration in mitochondria. Thus, the result would be the accumulation or depletion of metabolites at the point of entry into mitochondria. Hence, the membrane phase transitions in subcellular membranes could cause metabolic imbalance and provide one component of injury sustained by homeothermic cells during cold exposure.

There are a very large number of different, integrated chemical reactions that constitute common metabolic pathways within a cell. Each of these reactions will be affected in a different manner and to a different degree by cooling such that the possibility exists for uncoupling reaction pathways and producing harmful consequences. In preservation, cooling prolongs in vitro survival because it slows metabolism, reduces the demand for oxygen and other metabolites, and conserves chemical energy. However, it does not affect all reactions to the same extent, and the net result of cooling on an integrated, metabolizing system is complex, not entirely predictable, and not completely understood.

Studies of the effects of pure hypothermia on cell viability in the absence of any prior hypoxia have shown that the inactivation (killing) rates of cells exposed to reduced temperatures changes slope at approximately $7-8{ }^{\circ} \mathrm{C}$ implying that there are distinct mechanisms of hypothermic inactivation above and below this transition temperature. These values have been interpreted to suggest that unbalanced metabolism is probably the rate limiting step for hypothermic inactivation in the higher temperature range $\left(8-25^{\circ} \mathrm{C}\right)$, and membrane lipid phase transition or cold denaturation of a critical protein is likely to be responsible for the strong temperature dependence in the lower range $\left(<8^{\circ} \mathrm{C}\right)$.

\section{Effect upon Energy Metabolism}

Under normal circumstances the supply of energy-rich compounds to fuel a cell's requirement for homeostatic control is continuously replenished by oxidative phosphorylation in the mitochondria. During cooling however, there is a progressive exhaustion of chemical energy reserves in a cell despite the general suppressive effect of cooling on metabolism. The effect of cooling on metabolism is complex and should not be regarded as causing a simple uniform retardation of all biochemical reactions. For example, the complexity of low temperature effects on mitochondrial respiration is not limited to the impairment of translocase enzymes. It has been shown that other enzymes that control reactions of the tricarboxylic acid cycle and the electron transport chain are affected differently by cold storage. 


\section{Effect upon Ion Transport and Cell Swelling}

Intracellular ionic composition and volume regulation of a cell is maintained by a 'pump-leak' mechanism in which membrane bound enzymes transport various ions and solutes to counter the passive diffusion driven by chemical potential gradients. These active pumps are inhibited by hypothermia both by its direct effect on enzyme activity and by the depletion of high-energy reserves as mitochondrial energy transduction fails. Nevertheless, the resultant passive redistribution of ions and water across the cell membrane and the concomitant change in the membrane potential has been demonstrated to be rapidly and fully reversible in the short term and may not be a source of permanent injury. Cells are known to have inter-related cation transport systems depending on energy supply and are thereby affected by reduced temperatures. Moreover, it is recognized that changes in the distribution of divalent cations $\left(\mathrm{Ca}^{2+}, \mathrm{Mg}^{2+}\right)$, as a consequence of ischemia, hypoxia, and even cooling are especially important in cellular injury. The belief that $\mathrm{Ca}^{2+}$, in particular, is a mediator of cell death is based upon accumulated evidence over several decades from observations in a wide variety of tissues and pertains to cell death from a variety of causes. Cytosolic $\mathrm{Ca}^{2+}$ concentration is 10,000 fold lower than extracellular concentrations and it is now postulated that enhanced or unbalanced $\mathrm{Ca}^{2+}$ influx across the plasma membrane represents a final common pathway in cell death mediated by various conditions that share the tendency to induce an abnormal membrane permeability for $\mathrm{Ca}^{2+}$. In recent years, the recognition of the central role of $\mathrm{Ca}^{2+}$ mediated effects in the death of cells of ischemically sensitive tissues such as heart and brain has led to intense scrutiny of the effects of perturbations in divalent cation homeostasis. $\mathrm{Ca}^{2+}$ functions as a second messenger in the regulation of numerous biochemical and physiological processes often by activating regulatory proteins which, in turn, can activate many intracellular enzymes including protein kinases. It has been proposed that the significant protective effect of mild hypothermia against ischemic brain injury might be mediated in part by inhibition of $\mathrm{Ca}^{2+}$ induced effects and the prevention of inactivation of important $\mathrm{Ca}^{2+}$ dependent enzyme systems such as the kinases. However, it is generally recognized that cooling has no beneficial effect in preventing, and may even accentuate, inhibition of the $\mathrm{Ca}^{2+} \mathrm{Mg}^{2+}$ ATPase pump mechanism, which in general is the most important factor in controlling intracellular $\mathrm{Ca}^{2+}$ concentrations. The effects of cooling on $\mathrm{Ca}^{2+}$ homeostasis results not only from the inhibition of transmembrane pumping, but also from the inhibition of $\mathrm{Ca}^{2+}$ sequestration by intracellular organelles, particularly the endoplasmic reticulum and mitochondria.

\section{Proton Activity Changes}

The principal events of the ischemic cascade shows that elevation of the concentration of protons i.e. increasing acidity is regarded as a contributory central event in the process of cellular injury ensuing from $\mathrm{O}_{2}$ deprivation and energy depletion. Moreover, reduced temperatures are also known to influence $\mathrm{pH}$ regulation which is another important homeostatic mechanism for cell survival. It has frequently been reported that hydrogen ion concentration increases in a variety of mammalian cells during hypothermic storage such that tissue $\mathrm{pH}$ has been recorded to fall to 6.5-6.8 within a few hours of cold. Acidity is widely recognized as a hazard for cells, with the accumulation of protons contributing to a variety of deleterious processes including metabolic block of glycolysis and structural damage. Destabilization of lysosomes releasing harmful proteases and catalysis of oxidative stress by mobilization of free heavy metals have been implicated as mechanisms of cellular tissue injury during acidosis. A detailed account of acid-base regulation during hypothermia has recently been discussed elsewhere [2].

\section{Effect of Hypothermia on the Generation of Oxygen Derived Free Radicals}

The emerging role of oxygen derived free radicals (ODFR) in tissue injury and its participation in reperfusion injury is well established and discussed more fully in the next section relating to vascularized tissues and organs. In essence it is recognized that cooling increases the susceptibility of cells to produce free radicals and attenuates the natural defense mechanisms by which cells normally deal with the low level free radical production in metabolism. Due to a lower activation energy, free radical reactions are depressed less by temperature reduction than the enzymatic processes used to scavenge them. It is the balance between production and removal of free radicals that is crucial to the cell such that a combination of excessive radical generation and hindrance of normal defense mechanisms can redirect the processes in favor of injury. There is evidence that some of the natural defense mechanisms against free radicals become depleted during cold storage and that the addition of natural pharmacological scavengers including superoxide dismutase (SOD), catalase or mannitol to cold storage media may improve the viability of hypothermically stored organs. It is clear, therefore, that in tissues exposed to cold there is potential for unbalanced free radical reactivity and elevated intracellular free $\mathrm{Ca}^{2+}$ levels, and subsequent warming and reperfusion is likely to greatly potentiate these adverse events.

\section{Structural Changes}

The interrelationship between structure and function is fundamentally important for cellular homeostasis, which is governed by an intricate array of biochemical, physiological, and biophysical processes. Moreover, these processes are compartmentalized within the cell such that the structure of biological 
membranes and the cytoskeleton are integral components of cell viability and vitality.

The sensitivity of biological structures to temperature change is well known, and the thermal denaturation of proteins in particular is well documented. Thus most proteins, as well as nucleic acids and many polysaccharides, are able to exist in their biologically active states only within a limited temperature range that is characteristic of the macromolecule and its environmental conditions such as ionic strength and $\mathrm{pH}$. Whilst a great deal more is known about heat denaturation of proteins at elevated temperatures, there are well described examples of cold denaturation involving spontaneously unfolding of proteins or dissociation of the multi-subunit structure into biologically inactive species which may or may not reassemble on rewarming to normal temperatures.

It has been postulated on the basis of measurements in both model systems and intact cells that a phase separation occurs within the plane of the membrane as cooling proceeds. Such cold induced changes in the degree of membrane fluidity renders it thermodynamically unfavorable for membrane proteins to remain in the gel phase such that they may be redistributed laterally into regions of low melting point lipids that remain in the liquid crystalline phase. This process is thought to result in packing faults due to the development of lipid-rich and protein-rich microdomains in a membrane undergoing phase transitions. One consequence of this could be a change in membrane permeability and alteration in the solute barrier function of the membrane. Phase separation of mammalian membranes have been demonstrated at temperatures in the region of $10{ }^{\circ} \mathrm{C}$ and below, and this correlates with the trend towards increased permeabilities to both ions and even large molecules such as proteins during cooling. In addition to phase separations other forms of cold induced membrane damage include the actual loss of membrane phospholipids, which is intuitively more deleterious than phase changes that may in large part be reversible.

Cold induced changes of cellular structural proteins that constitute cytoskeletal components such as microtubules have been known since the mid 1970s. This cold sensitivity appears to be mediated by depolymerization of component polypeptide units and in general is readily reversible upon rewarming. Nevertheless, the possibility exists for reassembly of the microtubules in a way that results in cellular abnormalities.

\section{Vascular Injury during and Subsequent to Ischemia}

In addition to the injury sustained by parenchymal cells, it is now well established that ischemic organs are subject to further modes of injury relating to vascular effects. These are collectively referred to as the 'no-reflow' phenomenon and 'reperfusion injury', which has itself been shown to be a distinct phenomenon characterized by ultrastructural, functional, and metabolic alterations.

\section{No-Reflow Phenomenon}

It is a well established concern in isolated organ preservation for transplantation that blood flow can fail to return in an organ that has suffered a period of ischemia [13]. Clearly, this is of great importance in determining the fate of the transplanted organ, the health and viability of which depends critically upon the patency of its vascular network. Various mechanisms have been proposed to account for this phenomenon, which is also of crucial importance for the outcome of hypothermically stored organs. Contributory factors include ischemically induced vascular collapse, osmotic swelling of vascular endothelium leading to increased vascular resistance and vessel occlusion, and erythrocyte clumping producing blockage of capillaries and the formation of infarcts. The increased rigidity of red cells due to ATP depletion is considered to be a principal cause of reduced deformability and the most significant component of the no-reflow phenomenon. Weed et al. [14] proposed that ATP normally chelates intracellular $\mathrm{Ca}^{2+}$ and when ATP is no longer available, $\mathrm{Ca}^{2+}$ binds to membrane proteins, rendering the membrane more rigid. Additionally, it is known that the capillaries become increasingly leaky to protein after more than $30 \mathrm{~min}$ of ischemia, which would lead to loss of the onoctic pressure that retains fluid in the capillaries, and hence to an increase in the hematocrit within the vessels. This, in turn, would increase viscosity dramatically and lead to stagnation [15]. No-reflow during rewarming and reintroduction of blood into cold ischemic organs is now known to involve a network of complex interactions between vascular endothelium, blood components, and free radicals that is referred to as reperfusion injury [16-18].

\section{Reperfusion Injury}

The concept of reperfusion injury comes from the well-known fact that making a tissue hypoxic does not necessarily produce injury, but after reperfusion such tissues show marked and occasionally severe damage. Several possible interacting mechanisms of reperfusion injury are often described [16-18] and include:

i) cell derived free radicals (the oxygen paradox),

ii) actions and products of inflammatory cells in the blood, especially neutrophils and platelets,

iii) effects of intracellular $\mathrm{Ca}^{2+}$ accumulation (the calcium paradox),

iv) loss of membrane phospholipids.

The various proposed mechanisms of reperfusion injury are far from clear and remain under intensive investigation. While a detailed discussion of the various seemingly disjointed hypotheses is beyond the scope of this article, it is appropriate for subsequent discussion of the effects of hypothermia to include a few salient comments regarding the role of free radicals. 
During the past two decades, ODFR have been the focus of attention as mediators of various tissue injuries and particularly microvascular injury $[17,19]$. A free radical is a molecule with an odd, unpaired electron in its outer shell (denoted by a dot, thus $\mathrm{R}^{\bullet}$ ) and this chemically 'unsatisfied' electron renders the molecule highly unstable and reactive. Free radicals are inherently damaging since this high reactivity can precipitate chain reactions that produce increasingly reactive and toxic free radicals. Reactive species derived from oxygen are generated because oxygen normally undergoes tetravalent reduction to water by accepting four electrons simultaneously in the mitochondrial cytochrome oxidase system. However, as much as $2 \%$ of cellular oxygen undergoes univalent reduction, accepting one electron at a time and creating a superoxide anion $\left(\mathrm{O}_{2}^{-} \cdot\right)$, hydrogen peroxide, and eventually a hydroxyl free radical $\left(\mathrm{OH}^{\bullet}\right)$ :

$$
\mathrm{O}_{2} \stackrel{\mathrm{e}^{-}}{\longrightarrow} \mathrm{O}_{2}^{-} \stackrel{\mathrm{e}^{-}+2 \mathrm{H}^{+}}{\longrightarrow} \mathrm{H}_{2} \mathrm{O}_{2} \stackrel{\mathrm{e}^{-}+\mathrm{H}^{+}}{\longrightarrow} \mathrm{H}_{2} \mathrm{O}+\mathrm{OH}^{\bullet}
$$

The hydroxyl free radical is the most reactive of all and will oxidize any organic molecule almost instantaneously. The small quantities of free oxygen radicals produced during a cell's normal metabolism are detoxified by the enzyme SOD:

$$
\mathrm{O}_{2}^{-\bullet}+\mathrm{O}_{2}^{-\bullet}+2 \mathrm{H}^{+} \stackrel{\mathrm{SOD}}{\longrightarrow} \mathrm{H}_{2} \mathrm{O}_{2}+\mathrm{O}_{2}
$$

This protective enzyme occurs in all aerobic tissue but is found in substantial quantities only inside the cell. ODFR are also detoxified by the naturally occurring enzymes catalase and peroxidase. During ischemia, the production of hypoxanthine is greatly increased as a result of the catabolism of ATP. In the absence of oxygen, the enzyme xanthine dehydrogenase (XD) is converted to xanthine oxidase (XO), which converts hypoxanthine to xanthine, and this reaction also involves $\mathrm{Ca}^{2+}$. During reperfusion when the ischemic tissue is again exposed to oxygen, xanthine oxidase catalyzes the generation of superoxide radicals in the following reaction:

$$
\text { xanthine }+\mathrm{H}_{2} \mathrm{O}+2 \mathrm{O}_{2} \stackrel{\text { Xo }}{\longrightarrow} \text { uric acid }+2 \mathrm{O}_{2}^{-\bullet}+2 \mathrm{H}^{+}
$$

In tissues such as the myocardium, defense mechanisms against superoxide mediated ischemic injury are well developed in the form of scavenging enzymes. These may be antioxidants, such as glutathione peroxidase and catalase, or chain breaking antioxidants, such as SOD, ascorbate (vitamin $\mathrm{C}$ ), and $\alpha$-tocopherol (from vitamin $\mathrm{E}$ ). The emerging role of ODFR in ischemic injury has raised the question as to whether or not injury ascribed to ischemia is in fact reperfusion injury that is initiated by ischemia, but precipitated by reperfusion. This has led to the concept of scavenging free radicals both during ischemia and reperfusion. Hence, the role of drugs like allopurinol, which inhibits $\mathrm{XO}$ in preventing superoxide mediated injury is readily apparent. Also, compounds that chelate those transition metals such as iron which are known to catalyze the formation of free radicals and thereby contribute to tissue injury by initiating and propogating lipid peroxidation, have been shown to ameliorate tissue damage [20]. For example, desferroxamine inhibits the HaberWeiss reaction or more efficiently Fenton reaction in which highly reactive hydroxyl radicals are generated when $\mathrm{H}_{2} \mathrm{O}_{2}$ accepts an electron from a reduced metal ion such as $\mathrm{Fe}^{2+}[19]$. The end result of prolonged ischemia is cell death mediated by the mechanisms outlined above which characterize the process of necrosis, or pathological cell death. An alternative mode of cell death involving a programmed or regulated process involving de novo gene transcription and referred to as apoptosis has become a focus of attention in recent years.

\section{Apoptosis vs. Necrosis in Cold Induced Cell Death}

Injured or dying cells exhibit characteristic changes in cell morphology, and, as described above, the culmination of the deleterious events comprising the ischemic cascade is characterized by marked structural changes in cells and eventually cell death. It is now known that there are two distinct ways in which cells may die. Necrosis is caused by a general failure of cellular homeostatic regulation following injury induced by a variety of deleterious stimuli including hypoxia, toxins, radiation and temperature changes. Apoptosis ('programmed cell death') is by contrast a regulated process that has been distinguished from necrosis by numerous morphological biochemical and physiological differences [21, 22]. In regard to structural changes, apoptosis involves distinct morphologic features including blebbing of the plasma membrane but not loss of integrity, cell shrinkage with the formation of apoptotic bodies, chromatin condensation and internucleosomal DNA fragmentation in a specific non-random pattern. These characteristics are distinguishable from necrotic changes that involve degenerative processes such as cell and organelle swelling, rupture of plasma and lysosomal membranes and a random pattern of DNA degradation.

While many of the diverse stresses known to cause necrotic cell death have also been reported to induce apoptosis in a variety of cells, the role of low temperatures as a possible stimulus of programmed cell death has only recently begun to emerge [23]. The earliest reports appeared in 1990 when it was shown that cultured mammalian fibroblast cells at the transition from logarithmic to stationary growth were killed by brief exposures to $0{ }^{\circ} \mathrm{C}$ and rewarming to $37^{\circ} \mathrm{C}$ [24]. The observed cell killing required only a few minutes of hypothermic exposure, and the affected cells exhibited characteristics of apoptosis. Moreover, the kinetics of cell death served to distinguish cold induced apoptosis from the lethal effects of longer-term cold storage (hours or day), and also showed characteristics inconsistent with direct chilling injury (cold shock) [24]. More recently, we have reported that apoptosis can be detected in a significant proportion of both vascular smooth muscle and en- 
dothelial cells subjected to brief (30-120 s) cooling [25]. For both cell types, apoptosis was not found after exposure to hypothermia in the range +5 to $0{ }^{\circ} \mathrm{C}$, but was induced at lower temperatures, with a maximum response occurring at $-10{ }^{\circ} \mathrm{C}$ [25].

There is increasing evidence, therefore, that apoptosis may represent another manifestation of cold injury, but clearly all cells cannot be as susceptible as those used in the study of Nagle et al. [24]; otherwise hypothermic preservation for practical lengths of time would not be possible, which they are. Susceptibility to cold induced apoptosis is likely to depend critically upon the cell growth cycle [24] and the temperature of exposure [25]. Recent studies in cultured hepatocytes and liver endothelial cells have indicated that reactive oxygen species might play a key role in mediating cold induced apoptosis [26].

It is becoming increasingly more evident that apoptosis plays an integral role in cell death induced by the rigors of both hypothermia and cryopreservation [23, 24, 27-29]. More specifically, apoptosis has been identified to be directly associated with delayed onset cell death (DOCD). This is defined as death associated with cold exposure that is not apparent immediately upon rewarming, but extending over the post-exposure recovery period [29]. Recent research into the causative apoptotic and necrotic pathways responsible for low temperature induced DOCD has identified the contribution of multiple apoptotic pathways, including receptor and mitochondria induced apoptosis $[28,30]$. Investigations into these pathways, their progression, and their induction stressors has begun to facilitate new methods for improving preservation efficacy through the modulation of the cellular and molecular responses of a cell undergoing preservation (both hypothermic and cryopreservation) $[1,23,28,31-34]$.

The culmination of the cascade of interactive ischemic events is a tissue that is unable to resume its normal function upon restoration of its blood supply. The sequence of injurious processes advances at such a rate that irreversible damage is sustained by most organs within $1 \mathrm{~h}$ of ischemia at $37^{\circ} \mathrm{C}$, and at much shorter times in highly metabolic tissues such as cardiac muscle. The role of low temperatures in protecting against ischemic injury and providing a means for preserving tissues has been reviewed recently [2] and is summarized above for reference to a discussion of the applications for hypothermic blood substitution in surgery that will ensue in the remainder of this article.

\section{Need for Profound Hypothermia and Extreme Hemodilution or Blood Substitution}

On the basis of metabolic suppression alone, it was widely recognized long ago that mild or moderate hypothermia can provide a certain limited period of whole-body protection and that significant extension of this 'safe' interval of arrest (circu- latory and cardiac) would require the use of lower temperatures. Lower temperatures have been explored experimentally in a rational attempt to extend the tolerated limit of hypothermic circulatory arrest (HCA). Profound hypothermia arrest times of 90-120 min have been reported in dogs without evidence of neurological damage, but a significant proportion of animals died or had serious problems relating to hemorrhage, pulmonary edema, or other detrimental events. Moreover, early clinical use of profound hypothermia during CPB resulted in neurological complications even without circulatory arrest [35]. Following these experiences in the early 1960s profound hypothermia was not exploited clinically, and accepted limits for HCA have remained at $\leq 60 \mathrm{~min}$ with temperature no lower than $15^{\circ} \mathrm{C}[35,36]$.

The properties of hypothermia as applied to whole-body perfusion are not exclusively beneficial, and many of the complications manifesting after using lower temperatures are recognized to be associated with various deleterious effects of hypothermia on the blood per se. This has led to an essential requirement for hemodilution of patients that require operations involving CPB with adjunctive hypothermia. Hypothermia is associated with an increase in blood viscosity that contributes to red cell sludging in the microvasculature as well as to detrimental coagulopathies [37, 38].

\section{Clinical Hypothermia Demands Hemodilution}

Attempts to counteract the deleterious effects of cold on the blood, especially increasing viscosity that adversely effects blood flow, have involved hemodilution of the patient during CPB. Current CPB pump techniques employ blood dilution with aqueous salt solutions, a process referred to as crystalloid hemodilution, and this results in a noticeable improvement in the microcirculation over that achieved with blood priming $[39,40]$. The extent of hemodilution varies according to the degree of hypothermia, and dilution to a hematocrit of $20-25 \%$ is common in procedures using deep hypothermia $[8$, 41]. In such cases, the blood is diluted by about $50 \%$ using a variety of solutions, but the choice of diluent and the required extent of hemodilution remains controversial [36, 39]. Experimental studies have indicated that profound hemodilution is beneficial under conditions of profound hypothermia [42, 43]. In Japan, extreme hemodilution (to 7\% hematocrit) has been reported experimentally to protect the brain for neurosurgical operations [44], and clinically hemodilution to a hematocrit of $15 \%$ was reported to be safe for patients in a study of the effects of hemodilution on cerebral hemodynamics and oxygen consumption [45].

Although oxygen carrying capacity is decreased with hemodilution, $\mathrm{O}_{2}$ delivery and microcirculatory flow is increased as a result of the concomitant decrease in viscosity. This then compensates for the demonstrated association of hypothermia with a decrease in cerebral (and other organ) blood flow and 
Table 1. Advantages of complete exsanguination and blood substitution during controlled hypothermia for bloodless surgery
Permits use of deeper hypothermia

Avoids complications inherent in blood-based systems during hypothermia including:

Permits control of the extracellular environment directly and intracellular indirectly for cellular protection

Purging effect

Circulatory arrest unnecessary i) Provides more effective suppression of metabolism; extends tolerance to ischemia and minimizes oxygen demand.

ii) Practical benefit - 'buys more time'

i) Increased blood viscosity causing rheological problems and differential cooling.

ii) $\mathrm{O}_{2}$ dissociation from oxyhemoglobin poor $<20^{\circ} \mathrm{C}$ and stops at $12{ }^{\circ} \mathrm{C}$

iii) Coagulopathies

iv) Erythrocyte clumping and blockage of the microvasculature

Allows the design of hypothermic blood substitutes as universal tissue preservation solutions. Acellular crystalloid/colloid solutions designed to slow down ischemic events

Facilitates the wash-out of toxic endogenous or exogenous factors and shock mediators. Protect against reperfusion injury

i) Avoids necessity for mandatory circulatory arrest

ii) Low-flow perfusion of dispensable fluid is tolerated and preferred

iii) Provides clear field of view for surgery
$\mathrm{O}_{2}$ delivery [46]. As temperature decreases, the binding affinity between oxygen and hemoglobin increases, resulting in less efficient release of $\mathrm{O}_{2}$ at the tissue level, and the dissociation of $\mathrm{O}_{2}$ from oxyhemoglobin ceases at temperatures below 12 ${ }^{\circ} \mathrm{C}$ [47]. As deeper hypothermia is contemplated to extend the tolerance to ischemia, so the demand for greater degrees of hemodilution are needed to avoid the temperature related complications of blood based perfusion. The ultimate extreme of pursuing this strategy is $100 \%$ hemodilution or complete blood substitution. This has been researched for temperatures below $10^{\circ} \mathrm{C}$ when reliance upon oxyhemoglobin to supply the drastically reduced $\mathrm{O}_{2}$ demands of the profoundly hypothermic tissues is futile. UHBS is the approach we have explored by paying particular attention to the nature of the solutions used to substitute for the blood.

\section{Historical Basis for Hypothermic Blood Substitution}

The concept of total blood removal in conjunction with hypothermia is not new but prior to 1990 had not been explored extensively. Almost without exception all of the early studies used an extracellularly based solution and some attempted to use a colloid or a plasma based solution [48-52]. This in relation to the new approaches that were developed by our research group in the early 1990s has been reviewed elsewhere [1].

\section{The Allegheny Approach to Hypothermic Blood Substitutes with a Focus on the Design of the Substitute Solutions}

The feasibility of extending the present clinical limits of circulatory and/or cardiac arrest for bloodless surgery, without incurring unacceptable or irreversible ischemic changes, is posi- tively indicated both from scientific considerations and from the historical background for the application of hypothermia to total body preservation. Nevertheless, whilst a variety of experimental techniques have been explored, none has justified clinical consideration since the risk of complications remains too high after periods of arrest approaching 90-120 min. Throughout the history of the use of hypothermia in relation to clinical procedures, attempts to extend the acceptable limits of cardiac arrest have focused on a variety of important aspects of the technique [35, 53]. It is surprising, however, that relatively little attention has been devoted to the nature and composition of the solutions used either as hemodiluents, or as whole-body perfusates. Logically, it has been assumed that blood based perfusates provide the best medium for vascular perfusion during clinical hypothermic procedures, and this is justified by the principal requirement for continued and substantial demands for oxygen during mild or moderate hypothermia $\left(27-35^{\circ} \mathrm{C}\right)$. However, as mentioned above, it is well established that cooling induces detrimental changes to various properties of the blood that are not effectively ameliorated by simple hemodilution; these include dramatic increases in blood viscosity, coagulopathies and the deformability and clumping of erythrocytes which contribute significantly to the problem of multifocal blockage of the microvasculature and formation of tissue infarcts [54].

The concept of totally removing the blood and replacing it with a suitable acellular substitute solution is a novel approach, the feasibility of which we demonstrated in the 1990s $[34,37,55]$. In principle, this technique could provide a number of potential benefits over and above the obvious avoidance of the blood related complications. In addition to total vascular and capillary washout, and the removal of harmful catabolic products, blood substitution provides the opportunity to control the extracellular environment directly and the in- 
Table 2. Composition of new hypothermic blood substitutes compared with 'gold standard' organ preservation solutions

\begin{tabular}{|c|c|c|c|c|c|}
\hline Components & BMPS & UW & $\begin{array}{l}\text { Unisol-I } \\
\text { (ULK) }\end{array}$ & $\begin{array}{l}\text { Unisol-I } \\
\text { (UHK) }\end{array}$ & $\begin{array}{l}\text { Unisol-E } \\
\left(\mathrm{K}^{+} \text {free }\right)\end{array}$ \\
\hline \multicolumn{6}{|l|}{ Ionic, mmol/1 } \\
\hline $\mathrm{Na}^{+}$ & 100.0 & 30.0 & 100.0 & 62.5 & 147.2 \\
\hline $\mathrm{K}^{+}$ & 25.0 & 125.0 & 25.0 & 70.0 & - \\
\hline $\mathrm{Ca}^{2+}$ & 0.5 & - & 0.05 & 0.05 & 1.5 \\
\hline $\mathrm{Mg}^{2+}$ & 5.0 & 5.0 & 15.0 & 15.0 & 5 \\
\hline $\mathrm{Cl}^{-}$ & 1.0 & - & 30.1 & 30.1 & 122.0 \\
\hline $\mathrm{SO}_{4}{ }^{2-}$ & - & 5.0 & - & - & 1.0 \\
\hline \multicolumn{6}{|l|}{$\mathrm{pH}$ buffers, mmol/1 } \\
\hline $\mathrm{H}_{2} \mathrm{PO}_{4}^{-}$ & 25.0 & 25.0 & 2.5 & 2.5 & 1.2 \\
\hline $\mathrm{HPO}_{4}{ }^{2-}$ & - & - & - & - & - \\
\hline $\mathrm{HCO}_{3}^{-}$ & - & - & 5.0 & 5.0 & 25.0 \\
\hline HEPES & 10.0 & - & 35.0 & 35.0 & 25.0 \\
\hline \multicolumn{6}{|l|}{ Impermeants, mmol/1 } \\
\hline Lactobionate & - & 100.0 & 30.0 & 30.0 & - \\
\hline Raffinose & - & 30.0 & - & - & - \\
\hline Sucrose & - & - & 15.0 & 15.0 & - \\
\hline Mannitol & 30.0 & - & 25.0 & 25.0 & - \\
\hline Glucose & 10.0 & - & 5.0 & 5.0 & 5.0 \\
\hline Gluconate & 85.0 & - & 70.0 & 70.0 & - \\
\hline Ribose & 0.5 & - & - & - & - \\
\hline \multicolumn{6}{|l|}{ Colloids } \\
\hline HES & $5 \%$ & $5 \%$ & - & - & - \\
\hline Dextran 40 & - & - & $6 \%$ & $6 \%$ & $6 \%$ \\
\hline \multicolumn{6}{|l|}{ Pharmacologics } \\
\hline Adenosine, mmol/1 & - & 5.0 & 2.0 & 2.0 & 1.0 \\
\hline Glutathione, $\mathrm{mmol} / 1$ & 3.0 & 3.0 & 3.0 & 3.0 & 3.0 \\
\hline Allopurinol, mmol/1 & 1.0 & 7.4 & - & - & - \\
\hline Dexamethasone, mg/l & - & 8.0 & - & - & - \\
\hline Adenine, $\mathrm{mmol} / 1$ & 5.0 & - & - & - & - \\
\hline Insulin, $\mathrm{U} / \mathrm{l}$ & 40.0 & 100.0 & - & - & - \\
\hline Osmolality, mOsm/kg & - & 320 & 350 & 350 & 315 \\
\hline $\mathrm{pH}\left(25^{\circ} \mathrm{C}\right)$ & - & 7.4 & 7.6 & 7.6 & 7.5 \\
\hline$[\mathrm{K}+][\mathrm{Cl}-]$ & 25 & 0 & 752 & 2100 & - \\
\hline
\end{tabular}

BMPS = Belzer Machine Perfusion Solution (KPS1 from Organ Recovery Systems); $\mathrm{UW}=$ University of Wisconsin solution (Viaspan from Barr Laboratories); Unisol-I (ULK) = Unisol-Intracellular Base- Low Potassium (Organ Recovery Systems); Unisol-I (UHK) = Unisol-Intracellular Base- High Potassium (Organ Recovery Systems); Unisol-E = Unisol-Extracellular base (Organ Recovery Systems). tracellular milieu indirectly. Table 1 summarizes the recognized advantages of complete exsanguination and blood substitution during controlled hypothermia for bloodless surgery.

\section{New Aqueous Blood Substitutes for Brain Protection and in situ Tissue Preservation During 3.5 h of Profound Hypothermic Cardiac Arrest}

The concept of UHBS is appealing for several reasons: Deeper hypothermia can provide more effective suppression of metabolism, thereby extending the tolerance to ischemia and minimizing the demand for oxygen to levels that can be adequately supplied in a cold aqueous solution without the need for special oxygen carrying molecules. Complete exsanguination ameliorates the complications associated with increased viscosity, coagulopathies and erythrocyte clumping of cooled blood. Moreover, vascular purging can remove harmful catabolic products and formed elements that might participate in the ischemic and reperfusion injury cascades. Total exsanguination provides the opportunity to replace the blood with a more suitable fluid that can be designed to be protective under conditions of ultraprofound hypothermia. Solutes can be added to maintain ionic and osmotic balance at the cellular and tissue levels during hypothermia. Biochemical and pharmacological additives can help sustain tissue integrity in a variety of ways, including efficient vascular flushing, membrane stabilization, free radical scavenging and providing substrates for the regeneration of high energy compounds during rewarming and reperfusion. 
In essence, these are the principles that are embodied, to a greater or lesser extent, in the design of various solutions used for ex vivo preservation of isolated organs for transplantation $[15,56-58]$.

\section{The Organ Preservation Paradigm}

During the past 30 years, developments in the field of organ preservation have advanced to the point where isolated organs can be adequately stored for variable periods depending upon the nature of the organ: kidneys, livers and pancreases can be preserved for days, but the clinically accepted limits for hearts is only $6 \mathrm{~h}$ or less $[58,59]$. Whilst the limits of tolerance of neurological tissue to hypothermic storage has not been firmly established, cerebral recovery after $4 \mathrm{~h}$ of storage at $2 \pm$ $1{ }^{\circ} \mathrm{C}$ has been reported $[60,61]$. It seemed reasonable, therefore, on the basis of the established principles for isolated tissue preservation, to attempt to develop a technique for universal preservation of all the tissues of the body during a 3hour period of HCA. Three hours of arrest was set as a reasonable goal since there is justification for anticipating adequate survival of those organs and tissues most sensitive to ischemia and anoxia, i.e. heart and CNS, and $3 \mathrm{~h}$ would provide a generous window of opportunity for surgical intervention in the most complex of cases.

In contrast to the types of solutions that have been used historically as hemodiluents for clinical hypothermia, i.e. normal physiological 'extracellular-type' balanced salt solutions, our approach has been to design aqueous blood substitutes that embody many of the principles now identified as contributory and important for optimal organ preservation. Our working hypothesis was that acellular solutions can be designed to act as universal tissue preservation solutions during several hours of hypothermic whole-body washout involving cardiac arrest, with or without circulatory arrest. On this basis, we formulated and evaluated two new types of solutions designated 'Purge' and 'Maintenance' hypothermic blood substitutes (HBS) that fulfill separate requirements during the asanguineous procedure $[1,34,55,62,63]$. The principal solution (e.g. HTS/M or Unisol-I in table 2) is a hyperkalemic 'intracellular-type' solution specifically designed to 'maintain' cellular integrity during the hypothermic interval at the lowest temperature. The second solution (e.g HTS/P or Unisol-E in table 2) is designed to interface between the blood and the maintenance solution during both cooling and warming (fig. 1). This companion solution is, therefore, an 'extracellular-type' flush solution designed to aid in purging the circulation of blood during cooling since the removal of erythrocytes from the microvasculature is an important objective during ultraprofound hypothermia. The 'purge' solution is also designed to flush the system (vasculature and CPB circuit) of the hyperkalemic maintenance solution during warming and possibly help to flush-out accumulated toxins and metabolic by-products that might promote oxidative stress and free radical injury upon reperfusion.

- 'Intracellular-type' solution: A preservation solution that is typically hypertonic having a composition that is designed to restrict the passive exchange of water and ions during hypothermic exposure when cell membrane pumps are inhibited. This is achieved by raising the concentration of potassium, and reducing sodium, to mimic that of the intracellular space and thereby restrict passive fluxes of these ions. More importantly, an 'intracellular-type' solution usually includes a non-permeating (impermeant) anion to partially replace chloride ions in the extracellular space and thereby provide osmotic support to balance the intracellular oncotic pressure generated by macromolecules and their associated counter-ions locked inside the cell (these molecules do not cross the plasma membrane even passively due to their size and charge). Energy consuming pumps normally control the water content of cells, but during hypothermia (and/or energy depletion) this control mechanism is compromised and cells imbibe water due to the oncotic pressure of the intracellular milieu. Cell swelling due to this passive hydraulic flux can be inhibited by raising the osmolality of the extracellular medium and by incorporating an impermeant anion such as lactobionate, or gluconate. Hence, these biophysical characteristics are the basis of why such solutions have been termed intracellular-type' although in truth the solutions do not mimic the intracellular composition of the cytoplasm in many other respects.

- 'Extracellular-type' solution: By contrast, this is an isotonic solution having a plasma-like complement of ions that mimics the normal extracellular environment of cells. Examples of this type of solution can range from simple saline ('extracellular' in terms of the concentration of $\mathrm{NaCl}$ and osmolality) to tissue culture media that contain a more complete complement of ions, amino acids and other metabolites to mimic the extracellular composition of plasma and other body fluids. Such solutions are generally poor preservation solutions at reduced temperatures principally because they do not counteract the passive biophysical processes outlined above.

Based upon the principles that have emerged from isolated organ preservation studies, an attempt was made to incorporate the important characteristics in the formulation of the hypothermic blood substitute solutions, and wherever possible components that might fulfill multiple roles were selected. Conceptually, this strategy would maximize the intrinsic qualities of the solutions that, by design as universal tissue preservation solutions, would inevitably be a hybrid of other hypothermic perfusates and storage media.

The composition of the new hypothermic blood substitutes is listed in table 2, and the rationale for their formulation is described elsewhere [1, 34, 64-66]. These solutions have been shown to protect the brain, heart and visceral organs during 
Fig. 1. Temperature change profiles and perfusion schedules for two groups of dogs subjected to HBS during the Allegheny feasibility studies. Asanguineous perfusion fluid changes with either the Purge HBS (P), or Maintenance HBS (M) using an adapted CPB circuit are shown in the upper panel. Corresponding changes in hematocrit (\%), mean arterial blood pressure, and heart rate are shown in the lower panels.

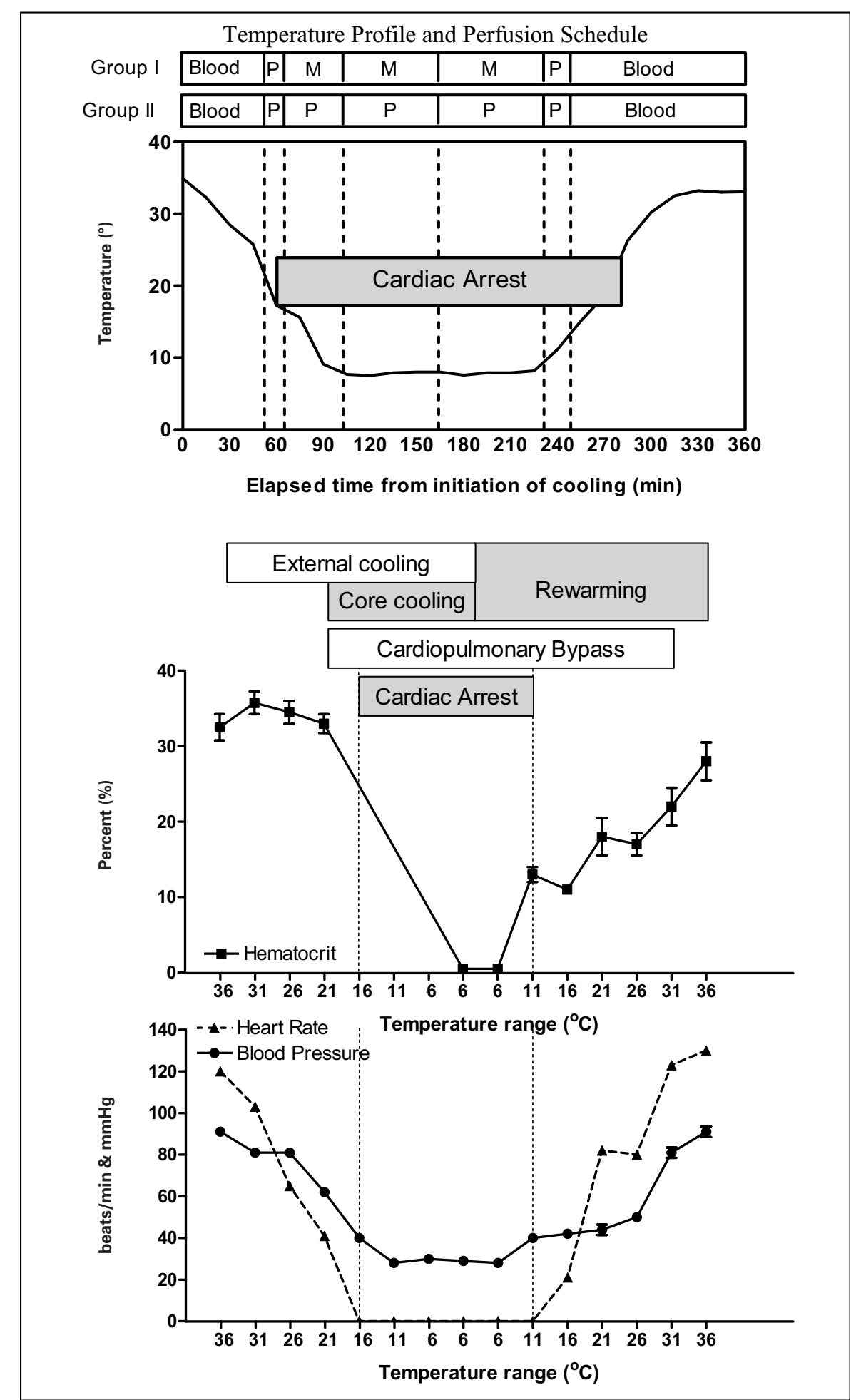

$3.5 \mathrm{~h}$ of cardiac arrest and global ischemia in an asanguineous canine model during controlled profound hypothermia at $<10{ }^{\circ} \mathrm{C}[1,34,55]$. More recently, this approach has been applied experimentally to animal models (porcine and canine) of hemorrhagic shock discussed more fully below [62, 63, 67-70].

\section{Pre-Clinical Models of Hypothermic Blood Substitutes}

\section{The Proof-of-Concept Allegheny Canine Model}

Initial studies to evaluate the concept of using these new HBS to effect 'clinical suspended animation' involving several hours of cardiac arrest was first explored in the early 1990s at 
Fig. 2. Canine Models of Hypothermic Blood Substitution. Serum enzyme profiles as markers of tissue injury in canine models of hypothermic blood substitution. Figures $2 \mathrm{~A}$ and 2B summarize mean $( \pm$ SEM) data for the Allegheny 'proof-ofconcept' model [1,34, 55] comprising two comparative groups of dogs (see text). In Group I (P/M/P) dogs were subjected to hypothermic blood substitution using a combination of Purge (P) and Maintenance (M) solutions and a nadir temperature of 7-10 ${ }^{\circ} \mathrm{C}$. Dogs in Group II were treated in the same way except they were perfused throughout with the Purge (P) solution only. Figure 2A shows the pre- and post-operative levels of total creatine kinase (CK) and figure 2B shows comparative changes for lactate dehydrogenase (LDH). Group I survivors showed only inconsequential and transient elevations in the measured enzymes compared with the marked and more persistent rises seen in the surviving dogs from Group II. Figure 2B shows that although serum levels of LDH were slightly elevated compared with the mean pre-operative levels for Group I experimental dogs, at no point did the values exceed the normal canine range (indicated by the dotted line). Figures $2 \mathrm{C}$ and 2D show the comparative changes in serum concentrations of the brain (CK-BB) and heart (CK-MB) isozyme fractions of CK in dogs subjected to hemorrhagic shock plus ultraprofound hypothermia and blood substitution [UHBS] $(\mathrm{P} / \mathrm{M} / \mathrm{P})[69]$ compared with the previous group of control dogs subjected to UHBS only without the prior shock phase $(\mathrm{n}=8)[34,55]$.
Allegheny University of the Health Sciences in Pittsburgh [1, $34,55,71,72]$. A brief synopsis of these studies is presented here.

\section{Methods}

Using a dog model, we employed a technique of asanguineous blood substitution with low flow perfusion and cardiac arrest below $10{ }^{\circ} \mathrm{C}$. Fourteen adult mongrel dogs were anesthetized and cannulated to establish extracorporeal cardiac bypass. As illustrated in figure 1 , initially surface cooling was employed and exsanguination was started at near $25^{\circ} \mathrm{C}$. In 11 dogs (experimental group, Group I) blood replacement was accomplished using the purge $(\mathrm{P})$ solution prior to exchange with the maintenance (M) solution. For comparison, three additional dogs (control group, Group II) were blood substituted and perfused throughout with the purge solution only. Following cardiac arrest, the cold solutions were continuously circulated for $3 \mathrm{~h}$ by the extracorporeal pump (flow rate $=40-85$ $\mathrm{ml} / \mathrm{kg} / \mathrm{min}$, mean arterial blood pressure (MABP): 25-40 mm $\mathrm{Hg}$ ). Intraoperative monitoring included systemic arterial, central venous pressures intracranial pressure), cerebral per- fusion pressure and pulmonary artery wedge blood pressures; heart rate; ECG; urinary output; brain, esophageal, subcutaneous, and rectal temperatures; and pump flow rates. The corresponding profiles for changes in heart rate, MABP, and hematocrit as a function of time and temperature are illustrated in figure 1 . The blood or perfusate was frequently sampled for blood gases and electrolyte analysis. At the end, the blood substitute was drained, and rewarming was started. The animals were autotransfused, weaned from the pump, decannulated, and observed for neurological, behavioral and biochemical functions during and after recovery.

\section{Results}

In the experimental group (Group 1) the heart usually started spontaneously in the temperature range $11-27^{\circ} \mathrm{C}$, and 8 animals showed rapid and full recoveries and continue to have survived long term (14-110 weeks) without experiencing any detectable neurological deficits. The remaining 3 animals recovered from the procedure but died or were sacrificed within the first week for a variety of reasons related principally to technical complications. These included tendencies for tissue 
Fig. 3. Tissue enzyme profiles in surviving large animal hemorrhagic shock models of hypothermic blood substitution.

Transient elevations of serum enzyme markers of tissue injury in a variety of large animal preclinical models of hemorrhagic shock prior to resuscitative hypothermia and blood substitution. Data is compiled from a selection of previously published studies [69, 89, 91]. In all cases elevations of serum concentrations of tissue enzymes induced by the procedure generally return to normal baseline levels within the first post-operative week supporting the notion that there is no longterm organ dysfunction.

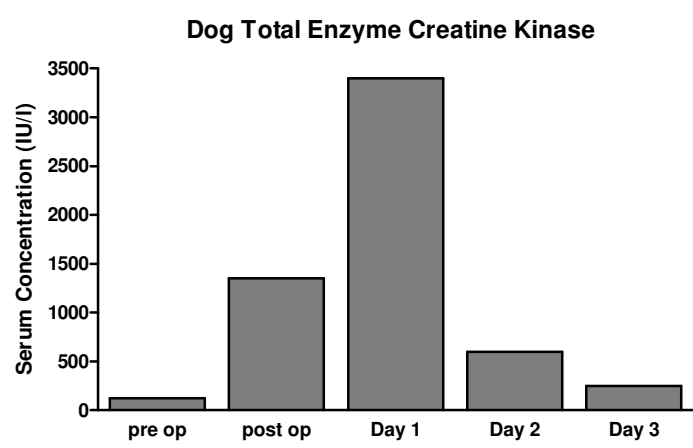

Pig Total Enzyme Lactate Dehydrogenase

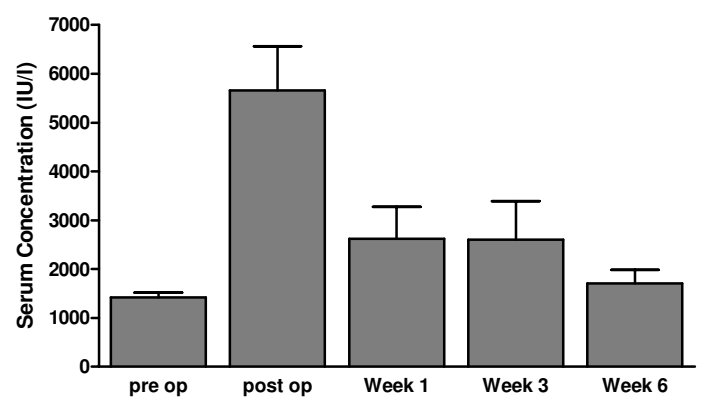

Pig Total Enzyme Creatinine Kinase

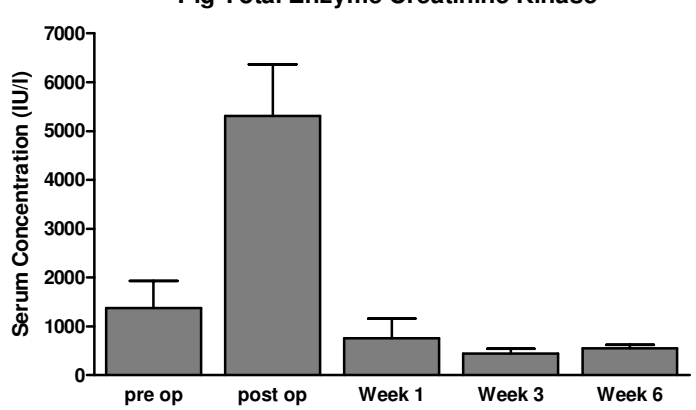

Pig Total Enzyme Aspartate Aminotransferase

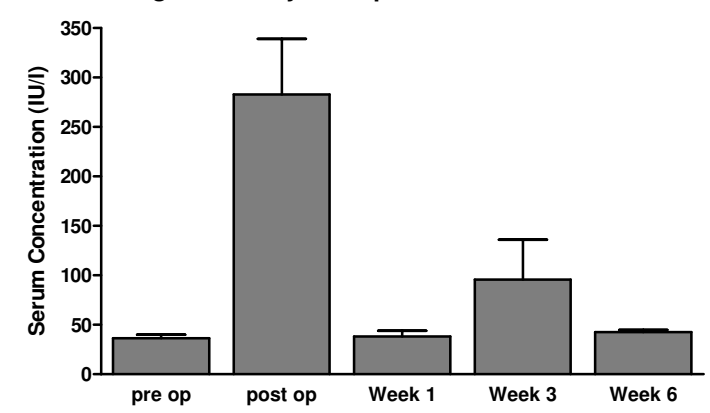

hemorrhage in one animal, and the development of seizures, possibly related to the site of placement of intracerebral monitoring probes in another dog. None of these phenomena were observed in the 8 long-term survivors. In the control group (Group II), 2 dogs survived after extensive and aggressive cardiac resuscitation measures. Postoperatively, they exhibited transient motor and sensory deficits during the first week.

A wide range of biochemical and hematological parameters were monitored on days 1, 2 and 3 and weeks 1,2 and 3 postoperatively in both groups. As shown in figure $2 \mathrm{~A}, \mathrm{~B}$, only inconsequential and transient elevations in enzymes in the brain, liver, muscle and heart were observed in the experimental group as compared with the much greater elevations in the control group. Immediate postoperative values (IU/1, mean \pm SEM) of several enzymes in the experimental vs. the control group are as follows:

- SGOT: $89 \pm 19$ vs. $734 \pm 540(\mathrm{p}=0.005)$,

- SGPT: $46 \pm 4$ vs. $98 \pm 52(\mathrm{p}=0.02)$,

- LDH: $114 \pm 11$ vs. $490 \pm 209(\mathrm{p}=0.0005)$;

and on day 1

- CK-BB: $108 \pm 22$ vs. $617 \pm 154(\mathrm{p}=0.002)$,

- CK-MB: $61 \pm 18$ vs. $1005 \pm 17(\mathrm{p}=0.03)$.

Neurological evaluation using neurological deficit scores (NDS) was based upon a modification of the Glasgow Out- come Scale: 0 = normal; 1 = minimal abnormality; 2 = weakness; 3 = paralysis; $4=$ coma; $5=$ death $[1,69]$. At postoperative days 1 and 2, NDS (mean \pm SEM) were: $0 \pm 0$ for the experimental group vs. $1.5 \pm 0.5$ for the control group. At postoperative days 3 and 7, NDS were $0 \pm 0$ vs. $1.0 \pm 1.0$. The faster neurological recovery of dogs treated with the 'intracellular-type' maintenance solution supports the biochemical data showing the benefits of this type of HBS for providing general tissue preservation in situ during extended periods of cardiac arrest.

These studies clearly established that this asanguineous hypothermic procedure with cardiac arrest and low flow perfusion of a synthetic blood substitute can be tolerated for $3 \mathrm{~h}$ and possibly more (not yet tested) without significant ischemic injury. Deep hypothermia can provide effective suppression of metabolism and cellular energy requirements, thereby extending the tolerance to ischemia by minimizing the demand for oxygen to levels that can be adequately supplied in a cold aqueous solution without the need for oxygen-carrying molecules. Moreover, complete exsanguination facilitates the removal of blood-borne mediators of ischemia and reperfusion injury and permits closer control of the extracellular environment by perfusion with a solution appropriately designed for the hypothermic conditions. 


\section{The Case for Improved Outcome Using an 'Intracellular-Type' Solution for UHBS}

The design of this Allegheny phase II study allowed some conclusions to be drawn concerning the quality of whole-body protection during hypothermic perfusion with aqueous blood substitute solutions. The combined strategic use of an 'extracellular-type' flush solution (HTS-P) and an 'intracellular-type' maintenance solution (HTS-M) not only minimized biochemical and physiological disturbances during the acute phase of recovery but also led to a more rapid return to normalcy with fewer neurological sequelae in the long-term survivors $[34,55]$. Earlier investigators had concluded that whilst improvements had been realized in their technique using Collins 'intracellular' solution, $2.5 \mathrm{~h}$ of circulatory arrest remained beyond the 'safe time limits' of hypothermic cardiac arrest [73]. In marked contrast, we demonstrate by our approach that $3 \mathrm{~h}$ of cardiac arrest is not beyond the safe limit when a procedure that maintains low flow perfusion of an appropriate whole-body wash-out solution is employed. The tolerance to total circulatory arrest was not tested in our model but we contend that by using a bloodless system the necessity for absolute circulatory arrest is circumvented. Moreover, there is a growing body of evidence that, even in a hemodiluted blood-based system, low-flow perfusion is superior to circulatory arrest resulting in less complications [74-76]. Comparisons of our reported findings with those reported by others, e.g. Kondo et al. [73], and even comparisons between the two groups within the Allegheny model study, clearly demonstrate a striking improvement in the quality and speed of recovery of animals resuscitated after low-flow hypothermic perfusion with the 'intracellular-type' HBS maintenance solution.

\section{Application of HBS to Resuscitation after Hemorrhagic Shock}

One of the conceivable prospective clinical applications of HBS might be as a life-saving adjunctive technique for surgical interventions in trauma and resuscitation medicine. In their erudite exposition that focuses on research initiatives, Safar and colleagues $[77,78]$ emphasized the future role of hypothermia in recovering patients from hemorrhagic injuries. Whilst hypothermia is a well established modality for protection and preservation when applied before or during an ischemic insult (e.g. during elective surgery), its value for resuscitation when applied after an ischemic event is less well understood. Early research in this area was focused on military needs to address the loss of combat soldiers who died from seemingly hopeless exsanguinating injuries [79, 80]. Clinical suspended animation implemented by using deep hypothermia was conceived as a potential solution in combat casualty care even though it was not until the last decade that such an aggressive and innovative technique was envisioned for use in civilian trauma cases $[1,65,69,78,81,82]$.

\section{Future Clinical Scenarios}

Clinical Suspended Animation - a Matter of Definition

In the context of combat casualty care, Safar's group [80] has chosen to define suspended animation in terms of circulatory arrest emphasizing stasis or no-flow as a critical component in addition to definitive cardiac arrest. However, in the special circumstance of hypothermic blood replacement that we have proposed as an alternative approach, we choose to extend the definition to include low-flow perfusion of synthetic blood substitutes under hypothermic conditions of cardiac arrest. We have outlined above the multifaceted advantages of complete exsanguination and blood substitution during controlled hypothermia for bloodless surgery [1, 69] (table 1). In practice, this approach avoids the necessity for mandatory circulatory arrest since low-flow perfusion of a dispensable fluid is tolerated and preferable. Under circumstances where CPB can be initiated, either in an elective operating room setting or by portable devices in an emergency situation such as combat casualty care, we define protection/preservation of the patient or trauma victim during lengthy periods of cardiac arrest, as 'clinical suspended animation'. A more acceptable term that describes the whole-body paralysis during hypothermic perfusion is 'corporoplegia' (used to define an asanguineous solution infused through the circulation during a period of global ischemia to minimize the deleterious effects of ischemia and subsequent reperfusion); this is consistent with the widely used terms for perfusion preservation of the heart (cardioplegia) and brain (cerebroplegia).

Recently, Alam [83] has reviewed all aspects of fluid resuscitation in the treatment of hemorrhagic shock for both military and civilian scenarios. Strategies to maintain cerebral and cardiac viability long enough to gain control of hemorrhage and restore vascular volume could be life-saving. It is now recognized that this requires an entirely new approach to the problem, with emphasis on rapid total body preservation, repair of injuries during metabolic arrest, and controlled resuscitation so-called EPR (emergency preservation and resuscitation) [83].

The feasibility of using UHBS as a new approach to enable resuscitation after hemorrhagic shock was also demonstrated in the mid-1990s using the Allegheny experimental model [69, 84]. The objective of that study was to evaluate the feasibility of UHBS and the new HBS solution as a protective modality after hemorrhagic shock and as a potential life-saving technique to facilitate surgical repair of intractable trauma cases. The study utilized our established canine model to compare the outcome with that reported previously and described above for dogs subjected to UHBS without the prior normothermic shock phase $[34,55]$.

The study was designed to imitate a clinical situation in which a trauma victim in shock responds initially to resuscitation (i.e. fluids, blood, manual compression of the bleeding site or 
clamping of the aorta) but is found to have an inaccessible injury (e.g. retrohepatic or suprahepatic venous injury). The scenario is that the initial resuscitation would enable the surgical team to safely cannulate and gradually cool the patient in preparation for definitive surgery. This study examined the outcome of a group of adult mongrel dogs subjected to hypothermic shock, short-term fluid resuscitation and UHBS for $2 \mathrm{~h}$ [69]. Our established canine model involving closedchest $\mathrm{CPB}$ was adapted to allow Wiggers-type controlled normothermic hemorrhagic shock (MABP $<50 \mathrm{~mm} \mathrm{Hg}$ ) for 30 min, followed by a brief (10 $\mathrm{min}$ ) resuscitation by infusion of fluids (crystalloids (Ringer's Lactate) and autologous blood). Both the extent of shock and its reversal in terms of cerebral blood flow were monitored using a transcranial Doppler technique. In each dog, the heart started spontaneously between $20-25^{\circ} \mathrm{C}$, at which point ventilation was restarted. All 8 dogs survived, all but one with complete neurological recovery. Blood chemistry samples examined immediately after the procedure showed significant differences $(\mathrm{p}<0.05)$ in only a few parameters such as CK (CK-BB and CK-MB; fig. $2 \mathrm{C}, \mathrm{D})$ compared with the previous group of control dogs reflecting the additional hypotensive insult. Figure 2C,D shows that these serological markers also normalized to baseline levels within 3-7 days, showing that there was no long-term organ dysfunction.

The neurological recovery indices and pathology in this series suggests a more consistent outcome was achieved in dogs that underwent UHBS with continuous low-flow perfusion. This is consistent with many recent clinical and experimental studies showing improved neurological outcome when lowflow hypothermic techniques are compared with similar procedures relying on circulatory arrest [10, 74-76, 85].

In other studies using their canine stasis model our collaborators at the University of Pittsburgh introduced the use of cold aortic saline flush at the start of cardiac arrest to rapidly induce protective hypothermia during prolonged cardiac arrest (120 min) for hemostasis followed by resuscitation [67, 68, 78]. These studies showed that a saline flush to a brain temperature of $10{ }^{\circ} \mathrm{C}$ resulted in normal survival after $90 \mathrm{~min}$, but not consistently after cardiac arrest $=120 \mathrm{~min}$. However, an additional study in which Unisol ${ }^{\circledR}$ (Organ Recovery Systems, Charleston, SC, USA) plus the antioxidant Tempol were evaluated as a comparative 'optimized flush', showed a markedly improved outcome (physiological, neurological and brain histology) after 120-min cardiac arrest compared with the saline flush $[67,68,78]$.

\section{Recent Advances Using a Pre-Clinical Porcine Hemorrhagic Shock Model}

To date, there have been no clinical studies to test the therapeutic benefits of hypothermia in trauma patients. However, well-designed preclinical studies clearly support the concept as outlined in the preceding sections. Although the proof-ofconcept studies are exciting, Alam [83] has recently pointed out that the clinical relevance of these studies was limited by pressure-controlled models of hemorrhagic shock, an absence of major injuries, and lack of surgical interventions. Attempts were therefore made to establish a more relevant, clinically realistic model using the pig. The first stage was to demonstrate that profound hypothermia could be induced through an emergency thoracotomy approach in an animal previously subjected to lethal vascular injuries and soft tissue trauma. This was achieved using a HBS (Unisol) with excellent longterm survival and no neurological damage or significant organ dysfunction [63] (fig. 2). In a follow-up study, Alam et al. [62] established that lethal vascular injuries, above and below the diaphragm, can be repaired under hypothermic cardiac arrest with $>75 \%$ long-term survival. More importantly, they showed that profound hypothermia could be used successfully, even after 60 min of normothermic shock, and that the surviving animals were not only neurologically intact but also had normal cognitive functions. Subsequent studies showed that the best outcomes were achieved using rapid induction of hypothermia $\left(2{ }^{\circ} \mathrm{C} / \mathrm{min}\right)$ and a slower rate of reversal $\left(0.5^{\circ} \mathrm{C} / \mathrm{min}\right.$ warming $)[70,86]$. Moreover, these studies using Unisol solutions for implementing HBS demonstrated the preservation of various cell types in the central nervous system, in addition to providing some immunological advantages [87, 88]. The optimum degree of hypothermic arrest using this preclinical model was also found to be $10{ }^{\circ} \mathrm{C}$, with lower temperatures resulting in worse survival outcomes [89]. This corroborates earlier findings using first-generation HBS solutions in the canine Allegheny model in which survival parameters were significantly better in dogs cooled to a nadir temperature of $7.4{ }^{\circ} \mathrm{C}$ compared with a group of dogs cooled to $1.4{ }^{\circ} \mathrm{C}$ [1]. Figure 2 illustrates serological markers of tissue enzyme profiles in a variety of published hemorrhagic shock models showing a transient elevation during the immediate postoperative period that returns to preoperative baseline values within 3-7 days. A substantial body of evidence is beginning to emerge supporting the notion that HBS is a highly effective modality for corporoplegia with excellent total body preservation. Parenthetically, we have suggested recently that beyond the obvious applications for surgical intervention, including treatment of traumatic injuries, this approach could be implemented for preserving organs in situ prior to harvesting for transplantation $[90,91]$. The overwhelming conclusion from these preclinical models of HBS in the treatment of exsanguinating hemorrhagic shock is that the scientific basis and expertise to preserve the viability of key organs and tissues during repair of otherwise lethal injuries now exists. This has provided the basis for current discussions aimed at designing a feasibility clinical trial to obtained translational data that might justify a wider application of this approach to trauma practice [83]. 
The future application of HBS for corporoplegia in trauma and EPR demands consideration of a variety of important variables in this multifaceted protocol. Some of the key issues, including the rates of cooling and warming, the optimum temperature and the type of solution, have been addressed and summarized in the preceding section. In the context of this article, the choice of solution used to effect cooling during EPR is clearly one of the principal considerations that can undoubtedly have a profound impact on outcome and in light of the available preclinical data must be given careful consideration. For example, the choice of whether to embark upon feasibility clinical trials using new HBS solutions such as the Unisol family of solutions used in preclinical models, or using more conventional fluids such as saline presents some debatable issues. On a scientific basis alone, there is little doubt that, just as in the field of ex vivo organ preservation, new 'intracellular-type' synthetic solutions provide a more appropriate platform for anticipating better outcomes than more simple 'extracellulartype' solutions. Normal or hypertonic saline are perhaps the simplest and most readily available in the clinic and have been used as the basis for some of the most respected preclinical research studies in the area of hypothermic resuscitation $[78,81$, 83]. Nevertheless, as the scientific evidence continues to build in favor of more complex, cytoprotective HBS solutions, inevitable ethical questions will have to be addressed in the planning of long-awaited clinical trials. The late great pioneer in this field, Peter Safar, drew particular attention to this point in discussing the future of clinical trauma resuscitation. In a broad sense he asked 'whether it is ethical to randomly withhold novel treatments that have improved long-term outcomes in clinically relevant large animal models' [81]. I personally argue that this consideration now applies specifically to the choice of acellular synthetic fluids that are available to affect corporoplegia and EPR. In light of the large animal studies completed in the last 10-15 years (reviewed in this article), the time is now right to open up a dialogue with regulatory agencies such as the FDA in order to that clinical pioneers are released from the constraints of using scientifically inferior solutions in planning the first clinical feasibility trials of EPR. Some, including this author, would argue that failure to use state-of-the-art solutions and ignore this evidence in favor of current regulatory constraints, cost, and availability would be an unethical step into the clinical future.
Successful application of a technique of hypothermic blood substitution to man would provide a more than 3-fold extension of the current limits of $<1 \mathrm{~h}$ for 'safe' arrest without a high risk of neurological complications. This novel approach to bloodless surgery would significantly broaden the window of opportunity for surgical intervention in a variety of currently inoperable cases, principally in the areas of cardiovascular surgery, neurosurgery and emergency trauma surgery. This provides further evidence for the protective properties of solutions such as the Unisol family of solutions used for global tissue preservation during whole-body perfusion in which the microvasculature of the heart and brain are especially vulnerable to ischemic injury [1]. Moreover, the application of solution design for clinical suspended animation and EPR under conditions of ultraprofound hypothermia, places HBS solutions such as Hypothermosol ${ }^{\circledR}$ (Biolife Solutions, Inc., Bothell, WA, USA) [82] and Unisol [65] in a unique category as a universal preservation media for all tissues in the body. In contrast, all other organ preservation media, including the most widely used commercial solutions such as UW (Viaspan ${ }^{\circledR}$; Wilmington, DE, USA) are established for specific organs, or groups of organs, e.g. UW for abdominal organs and celsior, cardiosol, or custodiol for thoracic organs [58, 92]. Moreover, the demonstrated efficacy of these synthetic, acellular HBS solutions justifies their consideration for multiple organ harvesting from cadaveric and heart-beating donors [91].

\section{Acknowledgements}

Innovative new techniques using profound hypothermia to effect what has historically been called 'clinical suspended animation' are now on the verge of being tried in the clinic. I am indebted to Dr. Andreas Sputtek for commissioning this article as a timely review of the research that has brought us to the point of considering clinical trials. I am privileged to have collaborated with many of the pioneers in this field and gratefully acknowledge their contributions here: Dr. Julian Bailes and Dr. Tommy Shih (formerly at Allegheny University in Pittsburgh); Dr. Peter Rhee and Dr. Hasan Alam (Uniformed Services University of Health Sciences, Bethesda and Massachusetts General Hospital, Harvard University); Dr. Sam Tisherman and Dr. Peter Safar (posthumously) (Safar Center for Resuscitation Research, Univ. Pittsburgh). Finally, Dr. John G. Baust for orchestrating the financial support for the Allegheny feasibility studies of hypothermic blood substitution and for introducing me to this challenging area of research.

\section{References}

1 Taylor MJ, Elrifai AM, Bailes JE: Hypothermia in relation to the acceptable limits of ischemia for bloodless surgery; in Steponkus PL (ed): Advances in Low Temperature Biology. London, JAI Press, 1996, vol 3, pp 1-64.

2 Taylor MJ: Biology of cell survival in the cold: the basis for biopreservation of tissues and organs; in Baust JG, Baust JM (eds): Advances in Biopreservation. Boca Raton, CRC Press, 2006, pp 15-62.
3 Swan H: Clinical hypothermia: A lady with a past and some promise for the future. Surgery 1973;73: 736-758.

4 Allen FM: Physical and toxic factors in shock. Arch Surg 1939;38:155-180.

5 Bigelow WG, Lindsay WK, Greenwood WF: Hypothermia. Its possible role in cardiac surgery: an investigation of factors governing survival in dogs at low body temperature. Ann Surg 1950;132: 849-866.
6 Swan H, Virtue RW, Blount SG, Kircher LJ: Hypothermia in surgery: analysis of 100 clinical cases. Ann Surg 1955;142:382-400.

7 Kramer RS, Sanders AP, Lesage AM, Woodhall B, Sealy WC: The Effect of profound hypothermia on preservation of cerebral ATP content during circulatory arrest. J Thorac Cardiovasc Surg 1968;56: 699-709. 
-8 Baumgartner WA, Silverberg GD, Ream AK, Jamieson SW, Tarabek J, Reitz BA: Reappraisal of cardiopulmonary bypass with deep hypothermia and circulatory arrest for complex neurosurgical operations. Surgery 1983;94:242-249.

9 Wells FC, Coghill S, Caplan HL, Lincoln C, Kirklin JW: Duration of circulatory arrest does influence the psychological development of children after cardiac operation in early life. J Thorac Cardiovasc Surg 1983;86:823-831.

10 Newburger JW, Jonas RA, Wernovsky G, Wypij D, Hickey PR, Kuban KCK, Farrell DM, Holmes GL, Helmers SL, Constantinou J, Carrazana E, Barlow JK, Walsh AZ, Lucius KC, Share JC, Wessel DL, Hanley FL, Mayer JE Jr, Castaneda AR, Ware JH: A comparison of the perioperative neurologic effects of hypothermic circulatory arrest versus low-flow cardiopulmonary bypass in infant heart surgery. N Engl J Med 1993;329:1057-1064.

11 Taylor MJ: Hypothermia; in Fink G (ed): Encyclopedia of Stress, 2nd ed. Amsterdam, Elsevier, 2007, in press.

12 Taylor MJ: Hypothermia; in Fink G (ed): Encyclopedia of Stress. San Diego, Academic Press, 2000, vol 2, pp 484-496.

13 Sheehan HL, Davis JC: Renal ischaemia with failed reflow. J Pathol Bacteriol 1959;78:105-120.

14 Weed RI, La Celle PL, Merrill EW: Metabolic dependence of red cell deformability. J Clin Invest 1969;48:795-809.

15 Pegg DE: Organ preservation; in Roberts AJ, Painvin GA (eds): The Surgical Clinics of North America. Philadelphia, W.B. Saunders, 1986, vol 66, pp 617-632.

16 Hallenbeck JM, Dutka AJ: Background review and current concepts of reperfusion injury. Arch Neurol 1990;47:1245-1254.

17 Das DK: Pathophysiology of Reperfusion Injury. Boca Raton, CRC Press, 1993.

18 Grace PA: Ischaemia - reperfusion injury. Br J Surg 1994;81:637-647.

19 Kukreja RC, Hess ML: Free Radicals, Cardiovascular Dysfunction and Protection Strategies. Austin, R.G. Landes, 1994.

20 Smith DS: Free radical scavengers and protection against ischemic brain damage; in Schurr A, Rigor BM (eds): Cerebral Ischemia and Resuscitation. Boca Raton, CRC Press, 1990, pp 373-388.

21 Evans RB, Cidlowski JA: Apoptosis: cellular signaling and molecular mechanisms; in Lemasters JJ, Oliver C (eds): Cell Biology of Trauma. Boca Raton, CRC Press, 1995, pp 25-47.

22 Leach AP: Apoptosis: molecular mechanism for physiological cell death. Clin Lab Sci 1998;11: 346-349.

23 Baust JM: Molecular mechanisms of cellular demise associated with cryopreservation failure Cell Preserv Technol 2002;1:17-32.

24 Nagle WA, Soloff BL, Moss AJ Jr, Henle KJ: Cultured Chinese hamster cells undergo apoptosis after exposure to cold but nonfreezing temperatures. Cryobiology 1990;27:439-451.

25 Tatsutani K, Joye JD, Virmani R, Taylor MJ: In vitro evaluation of vascular endothelial and smooth muscle cell survival and apoptosis in response to hypothermia and freezing. CryoLetters 2005;26: 55-64.

26 Rauen U, Polzar B, Stephan H, Mannherz H G, De Groot H: Cold-induced apoptosis in cultured hepatocytes and liver endothelial cells: mediation by reactive oxygen species. Faseb J 1999;13: 155-168.
27 Hollister WR, Mathew AJ, Baust JG, et al: The effects of freezing on cell viability and mechanisms of cell death in an in vitro human prostate cancer cell line. Mol Urol 1998;2:13-18.

28 Baust JM, Van Buskirk R, Baust JG: Gene activation of the apoptotic caspase cascade following cryogenic storage. Cell Preserv Technol 2002;1: 63-80.

29 Baust JM, Vogel MJ, van Buskirk RG, Baust JG: A molecular basis of cryopreservation failure and its modulation to improve cell survival. Cell Transplant 2001;10:561-571.

30 Baust JM, Van Buskirk R, Baust JG: Cryopreservation of an engineered skin equivalent: the apoptosis paradigm. J Am Soc Mech Eng (Adv Heat Mass Transfer Biotechnol); 1999;363:71-76.

31 Yagi T, Hardin JA, Valenzuela YM, Miyoshi H, Gores GJ, and Nyberg SL.: Caspase inhibition reduces apoptotic death of cryopreserved porcine hepatocytes. Hepatology 2001;33:1432-1440.

32 Mathew AJ, Hollister WR, Addona T, Baust JG; van Buskirk R: Vitamin E and EDTA improve the efficacy of HypoThermosol implication of apoptosis. Vitr Mol Toxicol 1999;12:163-172.

33 Taylor MJ, Hunt CJ: A new preservation solution for storage of corneas at low temperatures. Curr Eye Res 1985;4:963-973.

34 Taylor MJ, Bailes JE, Elrifai AM, Shih S-R, Teeple E, Leavitt ML, Baust JG, Maroon JC: A new solution for life without blood: asanguineous low flow perfusion of a whole-body perfusate during 3 hours of cardiac arrest and profound hypothermia. Circulation 1995;91:431-444.

35 Hickey PR, Andersen NP: Deep hypothermic circulatory arrest: a review of pathophysiology and clinical experience as a basis for anesthetic management. J Cardiothorac Anesth 1987;1:137-155.

36 Komer C: Physiologic changes of cardiopulmonary bypass; in Casthely PA, Bregman D (eds): Cardiopulmonary Bypass: Physiology, Related Complications, and Pharmacology. Mount Kisco, Futura Publishing Co., Inc., 1991, pp 37-84.

37 Bailes JE, Leavitt ML, Teeple E, Maroon JC, Shih S-R, Marquardt M, Elrifai AE, Manack L: Ultraprofound hypothermic with complete blood substitution in a canine model. J Neurosurg 1991;74: 781-788.

38 Patt A, McCroskey BL, Moore EE: Hypothermiainduced coagulopathies in trauma. Surg Clin N Am 1988;68:775-785.

39 Tobias MA: Choice of priming fluids; in Taylor KM (ed): Cardiopulmonary Bypass: Principles and Management. London, Chapman \& Hall, 1986, pp 222-248.

40 Austin JW, Harner DL: The heart-lung machine and related technologies of open heart surgery Phoenix, Phoenix Medical Communication, 1986.

41 Spetzler RF, Hadley MN, Rigamonti D, Carter LP, Raudzens PA, Shedd SA, Wilkinson E: Aneurysms of the basilar artery treated with circulatory arrest, hypothermia, and barbiturate cerebral protection. J Neurosurg 1988;68:868-879.

42 Popovic V, Popovic P: Survival of hypothermic dogs after 2-h circulatory arrest. Am J Physiol 1985;248: R308-R311.

43 Tisherman SA, Safar P, Radovsky AA, Peitzman A, Sterz F, Kuboyama K: Therapeutic deep hypothermic circulatory arrest in dogs: a resuscitation modality for hemorrhagic shock with irreparable injury. J Trauma 1990;30:836-847.

44 Ohta T, Sakaguchi I, Dong LW, Nagasawa S, Yasuda A: Selective cooling of brain using profound hemodilution in dogs. Neurosurgery 1992;31: 1049-1055.
45 Endoh H, Abe T, Tsukui A, Watanabe S, Shimoji, $\mathrm{K}$ : The effects of hemodilution on cerebral hemodynamics and oxygen consumption during non-pulsatile hypothermic cardiopulmonary bypass. Masui 1993;42: 376-381.

46 Utley JR, Wachtel C, Cain RB, Spaw EA, Collins JC, Stephens DB: Effects of hypothermia, hemodilution, and pump oxygenation on organ water content, blood flow and oxygen delivery, and renal function. Ann Thorac Surg 1981;31:121-133.

47 Anson JA, McCormick J, Zambramski JM: Oxygen dissociation characteristics of hemoglobin and blood substitute in relation to temperature. BNI Quarterly 1992;8:35-42.

48 Klebanoff G, Phillips J: Temporary suspension of animation using total body perfusion and hypothermia: a preliminary report. Cryobiology 1969;6: 121-125.

49 Haff RC, Klebanoff G, Brown RG, Koreski WR Asanguineous hypothermic perfusion as a means of total organism preservation. J Surg Res 1975;19: 13-19.

50 Connolly JE, Roy A, Guernsey JM, Stemmer EA Bloodless surgery by means of profound hypothermia and circulatory arrest. Ann Surg 1965;162: 724-737.

51 Neely WA, Turner MD, Haining JL: Survival after asanguineous total body perfusion. Surgery 1963; 54:244-249.

52 Neely WA, Turner MD, Haining JL: Asanguineous total-body perfusion. J Am Med Assoc 1963;184 718-721.

53 Hickey PR: Deep hypothermic circulatory arrest: current status and future directions. Mt Sinai J Med 1985;52:541-547.

54 Keen G, Gerbode F: Observation on the microcirculation during profound hypothermia. J Thorac Cardiovasc Surg 1963;45:252-260.

55 Taylor MJ, Bailes JE, Elrifai AM, Shih TS, Teeple E, Leavitt ML, Baust JG, Maroon JC: Asanguineous whole body perfusion with a new intracellular acellular solution and ultraprofound hy pothermia provides cellular protection during 3.5 hours of cardiac arrest in a canine model. Asaio J 1994;40:M351-M358.

56 Belzer FO, Southard JH: Principles of solid-organ preservation by cold storage. Transplantation 1988 45:673-676.

57 Southard JH, Belzer FO: Organ transplantation; in Flye MW (ed): Principles of Organ Transplantation. Philadelphia, W.B. Saunders, 1989, pp 194 215.

58 De Loecker W: Hypothermia and preservation of organs in the liquid state; in Fuller BJ, Grout BWW (eds): Clinical Applications of Cryobiology. Boca Raton, CRC Press, 1991, pp 46-79.

59 Breen TJ, Keck B, Hosenpud JD, O'Connell JB, White R, Daily OP: Thoracic organ transplants in the United States from Oct 1987 through Dec1991: a report from the UNOS Scientific Registry for Organ Transplants; in Terasaki PI, Cecka JM (eds): Clinical Transplants 1992. Los Angeles. UCLA Tissue Typing Laboratory, 1993.

60 White RJ, Albin MS, Verdura J, Locke GE: Prolonged whole brain refrigeration with electrical and metabolic recovery. Nature 1966;209:1320.

61 White RJ: Brain; in Armand Karow Jr, David E.Pegg (eds): Organ Preservation for Transplantation. New York, Marcel Dekker, 1981 pp 655-674. 
62 Alam HB, Bowyer MW, Koustova E, Gushchin V, Anderson D, Stanton K, Kreishman P, Cryer CMT, Hancock T, Rhee P: Learning and memory is preserved after induced asanguineous hyperkalemic hypothermic arrest in a swine model of traumatic exsanguination. Surgery 2002;132:278-288.

63 Rhee P, Talon E, Eifert S, Anderson D, Stanton K, Koustova E, Ling G, Burris D, Kaufmann C, Mongan P, Rich NM, Taylor MJ: Induced hypothermia during emergency department thoractomy: an animal model. J Trauma 2000;48:439-447.

64 Dahdah NS, Taylor MJ, Russo P, Wagerle LC: Effects of hypothermosol, an experimental acellular solution for tissue preservation and cardiopulmonary bypass, on isolated newborn lamb coronary vessels subjected to ultra profound hypothermia and anoxia. Cryobiology 1999;39:58-68.

65 Taylor MJ: System for Organ and Tissue Preservation and Hypothermic Blood Substitution. Assigned to Organ Recovery Systems, Inc. US Patent 628,311(6,492,103). 12-10-2002.

66 Brockbank KG, Taylor MJ: Tissue preservation; in Baust JG, Baust JM (eds): Advances in Biopreservation. Boca Raton, CRC Press, 2006, pp 157-196.

67 Behringer W, Safar P, Nozari A, Wu X, Kentner R, Tisherman SA, Radovsky A, Taylor MJ: Intact survival of 120 min cardiac arrest at $10{ }^{\circ} \mathrm{C}$ in dogs. Cerebral preservation by cold aortic flush (and novel solutions). Crit Care Med 2001;29:225.

68 Behringer W, Safar P, Kentner R, Wu X, Radovsky A, Tisherman SA, Taylor MJ: Novel solutions for intra-ischemic aortic cold flush for preservation during $30 \mathrm{~min}$ cardiac arrest in dogs. Crit Care Med 2001;29:226.

69 Simon D, Taylor MJ, Elrifai AM, Shih S-H, Bailes JE, Davis D, Kluger Y, Diamond DL, Maroon JC: Hypothermic blood substitution enables resuscitation after hemorrhagic shock and 2 hours of cardiac arrest. Asaio J 1995;41:M297-M300.

70 Alam HB, Chen Z, Honma K, Koustova E, Querol R, Jaskille A, Inocencio R, Ariaban N, Toruno K Rhee P: The rate of induction of hypothermic arrest determines the outcome in a swine model of lethal hemorrhage. J Trauma 2004;56:961.

71 Bailes JE, Elrifai AM, Taylor MJ, Shih SR, Teeple E, Leavitt ML, Baust JG, Maroon JC: Ultra-profound hypothermia combined with blood substitution: a new protocol for extending the safe limits of cardiac arrest for up to three hours. Surg Forum 1993;XLIV:564-567.
72 Elrifai AM, Bailes JE, Leavitt ML, Teeple E, Shih S-R, Taylor MJ, Maroon JC, Ciongoli KA, Bazmi B, Devenyi C, Rosenberg I: Blood substitution: an experimental study. J Extra-Corporeal Tech 1992; 24:58-63.

73 Kondo Y, Turner MD, Bebin J, Hardy JD: Body responses and recovery after $21 / 2$ hour hypothermic circulatory arrest. Surgery 1974;76:439-446.

74 Swain JA, Anderson RV, Siegman MG: Low-flow cardiopulmonary bypass and cerebral protection: a summary of investigations. Ann Thorac Surg 1993; 56:1490-1492.

75 van der Linden J, Astudillo R, Ekroth R, Scallan $\mathrm{MJH}$, Lincoln C: Cerebral lactate release after circulatory arrest but not after low flow in pediatric heart operations. Ann Thorac Surg 1993;56: 1485-1489.

76 Greeley WJ, Kern FH, Meliones JN, Ungerleider RM: Effect of deep hypothermia and circulatory arrest on cerebral blood flow and metabolism. Ann Thorac Surg 1993;56:1464-1466.

77 Safar P: Cerebral resuscitation after cardiac arrest: research initiatives and future directions. Ann Emerg Med 1993;22:324-349.

78 Safar PJ, Tisherman SA: Suspended animation for delayed resuscitation. Curr Opin Anaesthesiol 2002;15:203-210.

79 Bellamy RF, Maningas PA, Vayer JS: Epidemiology of trauma: Military experience. Ann Emerg Med 1986;15:1384-1388.

80 Bellamy R, Safar P, Tisherman SA, Basford R, Bruttig SP, Capone A, Taylor MJ, et al: Suspended animation for delayed resuscitation. Crit Care Med 1996;24(suppl 2):S24-S47

81 Safar PJ, Tisherman SA: Trauma resuscitation: what have we learned in the last 50 years? Curr Opin Anaesthesiol 2003;16:133-138.

82 Taylor M J: Solutions for Tissue Preservation and Bloodless Surgery and Methods Using Same. Assigned to Cryomedical Sciences, Inc. US Patent (5,405,742). 1995. MD/USA.

83 Alam HB: An update on fluid resuscitation. Scand J Surg 2006;95:136-145.

84 Bailes JE, Elrifai AM, Taylor MJ, Shih S-R, Simon DM, Diamond DL: Combining ultraprofound hypothermia with blood substitution facilitates resuscitation from hemorrhagic shock. Surg Forum 1995; XLVI:567-569.
85 Jonas RA: Review of current research at Boston Children's Hospital. Ann Thorac Surg 1993;56: 1467-1472.

86 Alam HB, Rhee P, Honma K, Chen H, Ayuste EC Lin T, Toruno K, Mehrani T, Engel C, Chen Z Does the rate of rewarming from profound hypothermic arrest influence the outcome in a swine model of lethal hemorrhage? J Trauma 2006;60: 134-146.

87 Alam HB, Chen Z, Ahuja N, Chen H, Conran R, Ayuste EC, Toruno K, Ariaban N, Rhee P, Nadel A, Koustova E: Profound hypothermia protects neurons and astrocytes, and preserves cognitive functions in a swine model of lethal hemorrhage. J Surg Res 2005;126:172-181.

88 Chen Z, Chen H, Rhee P, Koustova E, Ayuste EC, Honma K, Nadel A, Alam HB: Induction of profound hypothermia modulates the immune/inflammatory response in a swine model of lethal hemorrhage. Resuscitation 2005;66:209-216.

89 Alam HB, Chen Z, Li Y, Velmahos G, DeMoya M, Keller CE, Toruno K, Mehrani T, Rhee P, Spaniolas $\mathrm{K}$ : Profound hypothermia is superior to ultraprofound hypothermia in improving survival in a swine model of lethal injuries. Surgery 2006;140:307-314.

90 Taylor MJ, Soleto E, Aultman D, Mancini MC Moulder PV, Owen D, Shih T, Brockbank KGM: Preclinical evaluation of Unisol: a single solution for both flush and perfusion preservation preservation of organs for transplantation. Cryobiology 2000;41:360

91 Taylor MJ, Rhee P, Chen Z, Alam HB: Design of preservation solutions for universal tissue preservation in vivo: demonstration of efficacy in pre-clinical models of profound hypothermic cardiac arrest. Transpl Proc 2005;37:303-307.

92 Baicu S Taylor MJ: Acid-base buffering in organ preservation solutions as a function of temperature: New parameters for comparing buffer capacity and efficiency. Cryobiology 2002;45:33-48. 